\title{
A modeling approach integrating microbial activity, mass transfer, and geochemical processes to interpret biological assays: An example for PCE degradation in a multi- phase batch setup
}

Murray, Alexandra Marie; Maillard, Julien; Jin, Biao; Broholm, Mette Martina; Holliger, Christof; Rolle, Massimo

Published in:

Water Research

Link to article, DOI:

10.1016/j.watres.2019.05.087

Publication date:

2019

Document Version

Peer reviewed version

Link back to DTU Orbit

Citation (APA):

Murray, A. M., Maillard, J., Jin, B., Broholm, M. M., Holliger, C., \& Rolle, M. (2019). A modeling approach integrating microbial activity, mass transfer, and geochemical processes to interpret biological assays: An example for PCE degradation in a multi-phase batch setup. Water Research, 160, 484-496.

https://doi.org/10.1016/j.watres.2019.05.087

\section{General rights}

Copyright and moral rights for the publications made accessible in the public portal are retained by the authors and/or other copyright owners and it is a condition of accessing publications that users recognise and abide by the legal requirements associated with these rights.

- Users may download and print one copy of any publication from the public portal for the purpose of private study or research.

- You may not further distribute the material or use it for any profit-making activity or commercial gain

- You may freely distribute the URL identifying the publication in the public portal 
This is a Post Print of the article published online $27^{\text {th }}$ May 2019 in Water Research. The publishers' version is available at the permanent link:

https://doi.org/10.1016/j.watres.2019.05.087

\section{A modeling approach integrating microbial activity, mass transfer, and geochemical processes to interpret biological assays: An example for PCE degradation in a multi-phase batch setup}

Alexandra Marie Murray ${ }^{\mathrm{a}}$, Julien Maillard ${ }^{\mathrm{b}}$, Biao Jin $^{\mathrm{c}}$, Mette M. Broholm ${ }^{\mathrm{a}}$, Christof Holliger ${ }^{\mathrm{b}}$, and Massimo Rolle $\mathrm{a}^{\mathrm{a}^{*}}$

${ }^{a}$ Department of Environmental Engineering, Technical University of Denmark, Kgs. Lyngby, DK2800, Denmark

${ }^{\mathrm{b}}$ Laboratory for Environmental Biotechnology, ENAC-IIE, Ecole Polytechnique Fédérale de Lausanne, 1015 Lausanne, Switzerland

${ }^{\mathrm{c}}$ State Key Laboratory of Organic Geochemistry, Guangzhou Institute of Geochemistry, Chinese Academy of Science, China

\section{Highlights}

- Modeling approach integrating mass transfer, geochemistry, and microbial activity

- Quantified PCE degradation in the presence of iron- and sulfate-reducers

- Model validated with hydro-chemical and T-RFLP data

- Flexible tool for experimental design and comprehensive interpretation 
Abstract

2 The rate at which organic contaminants can be degraded in aquatic environments is not only

3 dependent upon specific degrading bacteria, but also upon the composition of the microbial

4 community, mass transfer of the contaminant, and abiotic processes that occur in the environment.

5 In this study, we present three-phase batch experiments of tetrachloroethene (PCE) degradation by a

6 consortium of organohalide-respiring bacteria, cultivated alone or in communities with iron- and/or

7 sulfate-reducers. We developed a modeling approach to quantitatively evaluate the experimental results, comprised of chemical and biomolecular time series data. The model utilizes the IPhreeqc

9 module to couple multi-phase mass transfer between gaseous, organic and aqueous phases with

10 microbial and aquatic geochemical processes described using the geochemical code PHREEQC.

11 The proposed approach is able to capture the contaminant degradation, the microbial population 12 dynamics, the effects of multi-phase kinetic mass transfer and sample removal, and the geochemical

13 reactions occurring in the aqueous phase. The model demonstrates the importance of aqueous

14 speciation and abiotic reactions on the bioavailability of the substrates. The model-based

15 interpretation allowed us to quantify the reaction kinetics of the different bacterial guilds. The

16 model further revealed that the inclusion of sulfate-reducing bacteria lowers the rate of PCE

17 degradation and that this effect is moderated in the presence of iron-reducing bacteria.

\section{Introduction}

19 Biodegradation of organic contaminants in aquatic systems depends not only on the activity and metabolic capabilities of specific degraders but also on microbial community interactions and on

21 the coupling with mass transfer processes and aquatic chemistry. Microbial community function

22 determines the fate of organic chemicals both in natural systems such as groundwater aquifers,

23 riverbed sediments and hyporheic zones (Hamonts et al., 2012; Meckenstock et al., 2015;

24 Weatherill et al., 2018), and in engineered applications, including in-situ bioremediation 
interventions and wastewater treatment plants (e.g., Wells et al., 2011). Physical processes such as mass transfer between different phases, diffusion and hydrodynamic dispersion are also of key importance since they can be the rate-limiting step and thus the bottleneck for the degradation of organic compounds (e.g., Bauer et al., 2009a; Rolle et al., 2010; Rolle and Kitanidis, 2014; Thullner et al., 2012). Further control on contaminant biodegradation occurs through the feedback between microbial activity and abiotic reactions, including aqueous chemical speciation and precipitation/dissolution of reactive minerals (e.g., Appelo and Postma, 2005; Postma and Jakobsen, 1996; Prommer et al., 2009).

Chlorinated ethenes are organic contaminants of primary concern that are widespread in groundwater aquifers and threaten the health of riverbed sediments and surface water bodies (Imfeld et al., 2008; Schneidewind et al., 2014; Weatherill et al., 2018; Xu et al., 2019). The most important degradation pathway of chlorinated ethenes is reductive dehalogenation by organohaliderespiring bacteria $(\mathrm{OHRB})$, which can sequentially degrade the mother compounds such as tetrachloroethene (PCE) and trichloroethene (TCE), to daughter products cis-dichloroethene, vinyl chloride, and ultimately to the non-toxic ethene. This respiration process has been studied for more than two decades (Holliger et al., 1993), yet furthering understanding of how the interaction between microbial guilds, physical transport processes, and chemical reactions influences degradation kinetics can elucidate the functioning of degrader communities and will be instrumental to optimize bioremediation efforts.

\section{Studying these systems in situ is difficult because microbial communities with relatively low} biodiversity, such as those in groundwater sediments, can contain multiple thousands of taxa (Kotik et al., 2013). Hence, experimental studies with controlled conditions can increase our understanding of the interactions between different bacterial guilds (Marcus et al., 2013; Yu and Semprini, 2002). Cultivation of anaerobic microorganisms, both as pure cultures and as communities, is commonly 
49 done in small, septum-sealed, anoxic batches (Abe et al., 2009; Amos et al., 2007; Yu and

50 Semprini, 2004). These systems allow for the bacterial community members to intermingle in the

51 aqueous phase, which is key for microbial interactions, such as commensalistic OHRB-containing

52 communities, in which the OHRB are dependent upon fermenting bacteria for production of

53 electron donor. Another benefit of these systems is that a separate phase, such as a non-aqueous

54 phase liquid or a gaseous atmosphere containing a toxic compound or a substrate, can be added to

55 the setup. For organic contaminants such as chlorinated ethenes, an immiscible organic layer can be

56 added to the system; the high partition coefficients for PCE and TCE means that these compounds

57 preferentially remain in the organic phase, yet as organisms in the aqueous phase consume these

58 chemicals, a chemical gradient is maintained and the organic layer acts as a source and slowly

59 releases more substrate to the aqueous phase (Buttet et al., 2018; Holliger et al., 1993). Such slow,

60 mass transfer limited release allows addressing the issue of bacterial inhibition by the toxicity of

61 high substrate concentrations and increasing the experimental duration (Daugulis, 2001; Déziel et

62 al., 1999).

63 These experimental systems are useful, but determining microbial kinetic parameters, such as

64 affinity constants and maximum substrate utilization rates without accounting for the physical

65 characteristics of the experimental system would lead to erroneous interpretation (Buttet et al.,

66 2018). When substrate is meted out to the bacteria slowly and continuously, mass transfer across the

67 phase boundaries (e.g., aqueous-organic and organic-gaseous) impacts the apparent substrate

68 utilization rate, just as mass transfer limits bioavailability in natural systems (Aeppli et al., 2009;

69 Bauer et al., 2009a; Kampara et al., 2008; Thullner et al., 2008). Sequential sampling also impacts

70 the mass balance in the system. If an experimental system is small or if the amount of sample

71 removed is relatively large, the removal of mass by this mechanism must also be considered since it 
affects the distribution of the different fluid phases in the setup (Buchner et al., 2016; Buttet et al., 2018).

Increasing the complexity of the bacterial community can also increase the complexity of the chemical reactions that occur in the aqueous phase (Gadd, 2010). To understand biodegradation kinetics one must determine the true concentration of the available substrate, thus the aqueous speciation of the substrates in the media needs to be accounted for. Furthermore, abiotic reactions between dissolved species and mineral precipitation/dissolution can impact microbial degradation processes. This is particularly important for microbial communities containing iron-reducing bacteria (FeRB) and sulfate-reducing bacteria (SRB), which entails that iron-sulfur geochemical reactions occur. Although the focus is often the microbial degradation of the organic contaminants, there is continuous feedback between the aquatic geochemistry and microbial community that is essential to understanding community dynamics and, ultimately, the degradation process.

Although the experimental techniques described above are well-represented in the literature, the current state of numerical modeling for such systems does not cohesively incorporate these removal on the determination of microbial kinetic parameters (Chambon et al., 2013; Jin and Rolle, 2016; Kouznetsova et al., 2010; Malaguerra et al., 2011; Wade et al., 2016). In this study we present multi-phase microbial ecology experiments and a novel modeling tool used 
performed laboratory batch experiments to investigate the impact of iron (Fe(III)) and sulfate reduction by FeRB and SRB on PCE reduction by an OHRB consortium containing Candidatus Sulfurospirillum diekerktiae strain SL2-1. The experiments consisted of four batches of increasing ecological complexity: the first batch consisted of the OHRB consortium cultivated alone, the second and third batches consisted of the OHRB consortium cultivated with either the FeRB or $\mathrm{SRB}$, and the fourth batch consisted of all three guilds together. The proposed modeling approach is a coupling between a MATLAB ${ }^{\circledR}$-based mass transfer code (Buttet et al., 2018) and the widely used geochemical code PHREEQC (Parkhurst and Appelo, 2013). We demonstrate the utility of this modeling tool to quantitatively interpret the experimental observations yielded by each batch, including both chemical and molecular data. The model allowed us to: (i) elucidate the impact of $\mathrm{SRB}$ and FeRB on PCE degradation, (ii) quantify the respiration kinetics of the different bacterial guilds, and (iii) disentangle the contribution of the different physical, biological, and chemical processes that occur in the multi-phase batch systems to the experimental observations, which consisted of measured time series of chemical and biomolecular data.

\section{Materials and methods}

\subsection{Experiment}

\subsubsection{Cultures}

The OHRB consortium, SL2-PCEc, that was used in this study originated from a chlorinated ethene-contaminated aquifer and was enriched and maintained over several years (Buttet et al., 2013). The consortium contains Candidatus Sulfurospirillum diekertiae, which is capable of respiring PCE to TCE. The FeRB used in the experiments was Shewanella oneidensis strain MR-1 (Heidelberg et al., 2002); the SRB used was Desulfovibrio vulgaris Hildenburough (Heidelberg et al., 2004). S. oneidensis and D. vulgaris were selected as model FeRB and SRB, respectively, 
118 because both can use hydrogen and neither can use acetate as an electron donor (Fredrickson et al., 119 2008; Tang et al., 2007; Tao et al., 2014).

\subsubsection{Experimental setup}

121 The base medium used was phosphate-bicarbonate buffered with a low chloride concentration 122 (Holliger et al., 1993), the composition is listed in detail in Table S1. Medium components 123 (chemicals sourced from Sigma-Aldrich Chemie GmbH, Buchs, Switzerland) and concentrated 124 stocks were prepared with milliQ water and either autoclaved for $20 \mathrm{~min}$ at $121^{\circ} \mathrm{C}$ or filtered 125 through $0.22 \mu \mathrm{m}$ sterile filters. All medium components were added to $125-\mathrm{mL}$ autoclaved bottles 126 sealed with butyl rubber stoppers using sterile syringes. Aliquots of $45 \mathrm{~mL}$ of base medium were 127 prepared, and acetate, Fe(III)-citrate, and sulfate stock solutions were each added such that in the 128 finished medium, $2 \mathrm{mM}$ of carbon source, $5 \mathrm{mM}$ of Fe(III) source, and $5 \mathrm{mM}$ of sulfate source were 129 present. The headspace was replaced with a 4:1 mixture of hydrogen to carbon dioxide through 0.22 $130 \mu \mathrm{m}$ sterile filters. The initial starting pressure of each bottle was approximately 1.5 atm; hydrogen 131 was added to each batch in excess, and microbial activity is limited by the availability of the 132 electron acceptor in this study.

133 After the replacement of the headspace and before inoculation, $5 \mathrm{~mL}$ of $100 \mathrm{mM}$ PCE dissolved in 134 hexadecane was added to the system. Because hexadecane has a lower density than and is 135 immiscible with water, the hexadecane formed an organic layer between the aqueous and gaseous 136 compartments in the bottle. PCE has a hexadecane-water partition coefficient of approximately 1375000 , thus the pre-inoculation aqueous concentration was $20 \mu \mathrm{M}$ (Holliger et al., 1993). The bottles 138 were allowed to sit for 24 hours before inoculation, such that there was ample time for equilibration 139 of PCE between the phases before introduction of the bacteria. 
SL2-PCEc, S. oneidensis, and D. vulgaris were cultivated statically as separate inocula in a dark 37

$141{ }^{\circ} \mathrm{C}$ room. The same cell count of the relevant guilds was added to each batch. Inoculation of the experimental batches was timed such that all inocula were in the exponential growth phase. All batch experiments were grown in the same conditions as the inocula. All combinations were conducted with biological duplicates. Samples of $1.5 \mathrm{~mL}$ were removed for analytical and molecular analyses. The samples were taken at regular intervals, with no more than 12 hours between sample points, until constant chloride concentration values were obtained in all bottles, which occurred after 3.5 days.

\subsubsection{Molecular Methods}

149 Cell counts of each guild inoculum, in order to match cell counts of inocula, were quantified by 150 quantitative polymerase chain reaction (qPCR) using the universal primers detailed in the 151 Supplementary Information. Analysis of qPCR data was performed on a MIC apparatus (Bio 152 Molecular Systems). A standard curve was run in duplicate, and all samples were run in triplicate. 153 PCR and terminal restriction length polymorphism (T-RFLP) sample analysis for each experimental 154 batch were completed as described in the Supplementary Information. Although the T-RFLP 155 analysis does not give absolute cell count values, it allows tracking of the temporal evolution of the 156 entire community and verification that no unexpected population from the OHRB consortium 157 appears during the experimental duration. Fragment counts were converted into cell counts by 158 adjusting for the number of $16 \mathrm{~S}$ rRNA gene copies per genome for each species ( 1 gene copy cell $^{-1}$ 159 for $S$. diekertiae, 5 gene copies cell ${ }^{-1}$ for $D$. vulgaris, and 9 gene copies cell ${ }^{-1}$ for $S$. oneidensis) 160 (Buttet et al., 2018; Heidelberg et al., 2004, 2002).

\subsubsection{Analytical Methods}

$162 \mathrm{Fe}(\mathrm{II})$ concentrations were measured using a colorimetric ferrozine assay (Viollier et al., 2000).

163 Samples for ferrozine assay analysis were diluted ten times in $0.5 \mathrm{M} \mathrm{HCl}$ directly upon removal to 
164 prevent oxidation of $\mathrm{Fe}(\mathrm{II})$ to $\mathrm{Fe}(\mathrm{III})$ and to dissolve any $\mathrm{Fe}(\mathrm{II})$ precipitates (Zhou et al., 2017).

165 Samples were not filtered, and thus the total Fe(II) concentration was measured. Chloride

166 concentrations were determined via silver ion titration with a Chlor-o-counter (Flohr Instument,

167 Nieuwegein, Netherlands). Because SL2-PCEc is only capable of transforming PCE to TCE,

168 produced chloride is attributable to this single dechlorination step and PCE degradation can be

169 measured without chlorinated ethene quantification (Buttet et al., 2018). Sulfate was measured by

170 ion chromatography - suppressed conductivity detection (ICS-5000, Thermo Fisher). Samples were

171 pretreated by passing them through a cleanup-cartridge (1 cc, Dionex OnGurad II Na,

172 ThermoScientific) to remove divalent metal ions and protect the column and suppressor. Samples

173 for sulfate analysis were diluted five times in a 5\% zinc acetate solution directly upon removal to

174 trap sulfide as zinc sulfide. Samples for sulfate analysis were frozen at $-20^{\circ} \mathrm{C}$ until analysis.

\subsection{Modeling Approach}

176 The conceptual arrangement of the bacterial, multi-phase mass transfer, and aquatic geochemical

177 processes that occur in the multi-phase experimental setup are schematically represented in Figure

178 1. Mass transfer in the model is driven by both bacterial respiration (bolded and colored arrows,

179 Figure 1) and sample removal (block arrow, Figure 1). In this section, we first describe each process

180 individually and then present their combination in a modeling framework. 


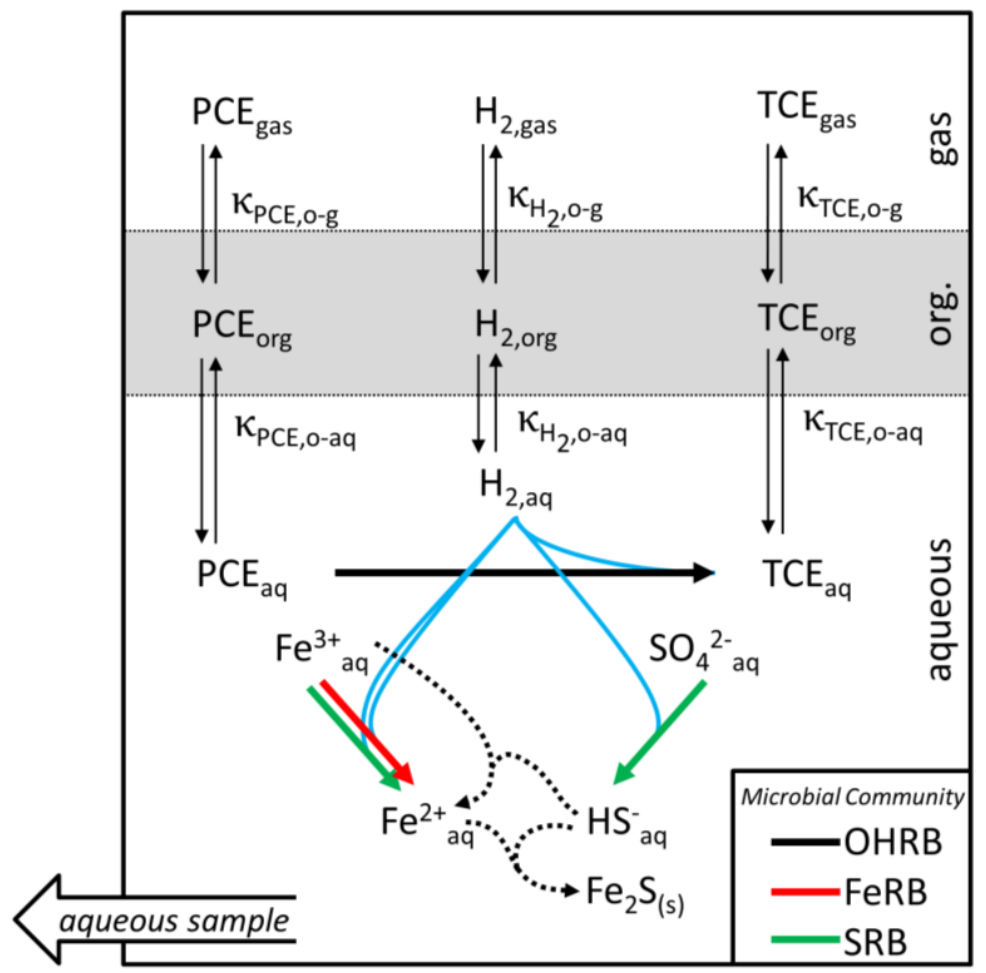

182 Figure 1. Conceptual model of the physical, chemical, and bacterial processes that occur in the

183 experimental setup, where $\kappa_{i, o-a q}$ is the mass transfer coefficient between the organic and aqueous

184 phases, and $\kappa_{i, o-g}$ between the organic and gas phases, for compound $i$. The thick black arrow

185 represents respiration by the OHRB Candidatus Sulfurospirillum diekerktiae, the thick red arrow

186 respiration by the FeRB Shewanella oneidensis, and the thick green arrows respiration by the SRB

187 Desulfovibrio vulgaris. Blue arrows respresent pathways in which hydrogen is consumed. Slim

188 black arrows represent mass transfer across phase boundaries. Dotted black lines represent

189 aquatic geochemical reactions. The block arrow indicates that the aqueous phase is removed

190 during sampling. 


\subsubsection{Bacterial Kinetics}

193 The bacterial processes (bolded and colored arrows, Figure 1), are the primary driving force for mass transfer and transformations that occur during the experiment. Double Monod kinetics were used to simulate the consumption of both the electron donor and electron acceptors (Rittmann and McCarty, 2001):

$$
\frac{d C_{a q, E A}}{d t}=-k_{\max } X\left(\frac{C_{a q, E D}}{C_{a q, E D}+K_{S, E D}}\right)\left(\frac{C_{a q, E A}}{C_{a q, E A}+K_{S, E A}}\right)
$$

197 where $d C_{a q, E A} / d t\left[\mathrm{~mol} \mathrm{~L}^{-1} \mathrm{~h}^{-1}\right]$ is the change in electron acceptor in the aqueous phase due to 198 bacterial processes, $C_{a q, E D}$ and $C_{a q, E A}[\mu \mathrm{M}]$ are the aqueous concentration of electron donor and 199 acceptor, $k_{\max }\left[\mathrm{mol} \mathrm{cell} \mathrm{s}^{-1} \mathrm{~s}^{-1}\right]$ is the maximum specific reduction rate, $X$ [cells $\left.\mathrm{L}^{-1}\right]$ is the biomass 200 concentration, $t[\mathrm{~s}]$ is time, and $K_{S, E D}$ and $K_{S, E A}[\mathrm{M}]$ are the half-saturation constants for the electron 201 donor and acceptor. The electron acceptors present in the media are PCE, Fe(III), and sulfate; 202 hydrogen was the electron donor for all guilds. The change in substrate is related to biomass by:

$$
\frac{d X}{d t}=Y_{E A} \frac{d C_{a q, E A}}{d t}-k_{d} X
$$

203 where $Y_{E A}$ [cells $\left.\mathrm{mol}^{-1}\right]$ is the biomass yield on the electron acceptor and $k_{d}\left[\mathrm{~s}^{-1}\right]$ is the linear decay coefficient. Equations 1 and 2 were applied for OHRB respiration of PCE to TCE, FeRB respiration of $\mathrm{Fe}(\mathrm{III})$ to $\mathrm{Fe}(\mathrm{II})$, and $\mathrm{SRB}$ respiration of sulfate to sulfide. D. vulgaris, the SRB used in the experiment, is also capable of respiring Fe(III). Elias et al. (2004) document this respiration to follow first-order kinetics, dependent only on the concentration of Fe(III), and both Elias et al. (2004) and Park et al. (2008) demonstrate that growth does not occur when reducing this metal ion.

$\mathrm{Fe}(\mathrm{III})$ reduction by SRB was thus modeled by: 


$$
\frac{d C_{a q, F e(I I I)}}{d t}=-k_{F e B i o} C_{F e(I I I), B i o}
$$

210 where $k_{F e B i o}\left[\mathrm{~s}^{-1}\right]$ is the first-order rate constant. The SRB D. vulgaris is modeled as capable of

211 respiring both aqueous Fe(III) and sulfate, depicted by the green arrows in Figure 1. The

212 bioavailable Fe(III) is thus used as an electron acceptor by two guilds included in the experiments.

213 Table 1. Stoichiometry for respiration and cell synthesis half reactions

\begin{tabular}{l|l}
\hline Reaction & Stoichiometry \\
\hline $\mathrm{R}_{\mathrm{ED}}$ & $\frac{1}{2} \mathrm{H}_{2} \rightarrow H^{+}+e^{-}$ \\
\hline $\mathrm{R}_{\mathrm{Bio}}$ & $\frac{1}{2} \mathrm{CH}_{3} \mathrm{COO}^{-}+\frac{1}{4} \mathrm{CO}_{2}+\frac{1}{4} \mathrm{NH}_{4}^{+}+\frac{5}{4} \mathrm{H}^{+}+e^{-} \rightarrow \frac{1}{4} \mathrm{C}_{5} \mathrm{H}_{7} \mathrm{O}_{2} \mathrm{~N}+\mathrm{H}_{2} \mathrm{O}$ \\
\hline $\mathrm{R}_{\mathrm{EA}}: \mathrm{PCE}$ & $\frac{1}{2} \mathrm{C}_{2} \mathrm{Cl}_{4}+\mathrm{H}^{+}+e^{-} \rightarrow \frac{1}{2} \mathrm{C}_{2} \mathrm{HCl}_{3}+\frac{1}{2} \mathrm{H}^{+}+\frac{1}{2} \mathrm{Cl}^{-}$ \\
\hline $\mathrm{R}_{\mathrm{EA}}: \mathrm{Fe}^{3+}$ & $\mathrm{Fe}^{3+}+e^{-} \rightarrow \mathrm{Fe}^{2+}$ \\
\hline $\mathrm{R}_{\mathrm{EA}}: \mathrm{SO}_{4}^{2-}$ & $\frac{1}{8} \mathrm{SO}_{4}^{2-}+\frac{19}{16} \mathrm{H}^{+}+e^{-} \rightarrow \frac{1}{16} \mathrm{H}_{2} S_{(g)}+\frac{1}{16} \mathrm{HS}^{-}+\frac{1}{2} \mathrm{H}_{2} \mathrm{O}$ \\
\hline
\end{tabular}

215 The hydrogen oxidation, cell synthesis, and PCE, Fe(III), and sulfate reduction half reactions (Table

216 1) were balanced using the method by Rittmann and McCarty (2001). The total stoichiometric

217 reaction for each guild was obtained by a linear combination of the half reactions in Table 1:

$$
R_{\text {Total }}=f_{S}\left(R_{\text {Bio }}+R_{E D}\right)+f_{e}\left(R_{E A}+R_{E D}\right)
$$

218 where $R_{B i o}, R_{E D}$, and $R_{E A}$ are the half reactions for biomass synthesis, the electron donor, and the

219 electron acceptor, respectively, and $R_{\text {total }}$ is the combined reaction. $f_{s}$ and $f_{e}$ are the fractions of 220 electrons utilized for cell synthesis and energy production, respectively, which are calculated based 221 on the yield factor, $Y_{E A}$, expressed as $\left[\mathrm{mol}_{\text {biomass }} \mathrm{mol}^{-1}\right]$. Moles of biomass are assumed to be 222 represented by the formula $\mathrm{C}_{5} \mathrm{H}_{7} \mathrm{O}_{2} \mathrm{~N}$ (Holliger et al., 1993) and each cell to have a mass of $2231.72 \times 10^{-13} \mathrm{~g} \mathrm{cell}^{-1}$ (Balkwill et al., 1988). Growth does not occur during Fe(III) respiration by SRB, 224 thus $f_{s}$ for this process is zero and all electrons are used for energy $\left(f_{e}=1\right)$. For all other reactions, 
cell synthesis was modeled to occur via the same stoichiometry for all bacterial guilds. It has been found that approximately $70 \%$ of cell carbon for anaerobic bacteria is sourced from acetate and approximately 30\% from $\mathrm{CO}_{2}\left(R_{\text {Bio }}\right.$, Table 1) (Badziong and Thauer, 1978; Holliger et al., 1993). $\mathrm{Fe}(\mathrm{III})$ reduction by FeRB and SRB followed the same stoichiometry.

\subsubsection{Multi-phase Kinetic Mass Transfer}

230 The movement of the electron donor and acceptor between the phases are represented by the slim,

231 black arrows in the conceptual model (Figure 1). The differential equations 5, 6, and 7 describe the 232 change in concentration of each relevant compound in each compartment by kinetic mass transfer 233 (Aeppli et al., 2009; Jin et al., 2013):

$$
\begin{gathered}
\frac{d C_{a q, i}}{d t}=\frac{\left(\frac{d n_{i}}{d t}\right)_{g a s-a q}}{V_{a q}}+\frac{\left(\frac{d n_{i}}{d t}\right)_{\text {org }-a q}}{V_{a q}} \\
\frac{d C_{\text {org }, i}}{d t}=\frac{-\left(\frac{d n_{i}}{d t}\right)_{\text {org }-a q}}{V_{\text {org }}}+\frac{-\left(\frac{d n_{i}}{d t}\right)_{\text {org-gas }}}{V_{\text {org }}} \\
\frac{d C_{g a s, i}}{d t}=\frac{-\left(\frac{d n_{i}}{d t}\right)_{\text {gas }-a q}}{V_{\text {gas }}}+\frac{\left(\frac{d n_{i}}{d t}\right)_{\text {org-aq }}}{V_{\text {gas }}}
\end{gathered}
$$

234 where $d C_{i, p} / d t\left[\mathrm{~mol} \mathrm{~L}^{-1} \mathrm{~s}^{-1}\right]$ is the change in concentration for the compound, $i$, in phase, $p, V_{p}[\mathrm{~L}]$ is

235 the volume of phase $p$, and $d n_{i} / d t\left[\mathrm{~mol} \mathrm{~s}^{-1}\right]$ is the total change in moles between phases for the 236 compound. PCE, TCE, and hydrogen were modeled to move between the phases, and movement 237 from the organic phase is defined as positive. Hydrogen concentrations were calculated based on the 238 known initial pressure in and fractional composition of the headspace and the ideal gas law. The 239 movement of mass across the two relevant phase interfaces, $\left(d n_{i} / d t\right)_{\text {org-aq }}$ and $\left(d n_{i} / d t\right)_{\text {org-gas }}$, is 240 described by Equations 8 and 9 (Aeppli et al., 2009): 


$$
\begin{gathered}
\left(\frac{d n_{i}}{d t}\right)_{o r g-a q}=V_{a q}\left(C_{a q, i}^{e q}-C_{a q, i}\right)\left(\frac{\kappa_{o r g-a q, i} \cdot A}{V_{o r g}}\right) \\
\left(\frac{d n_{i}}{d t}\right)_{o r g-g a s}=V_{g a s}\left(C_{g a s, i}^{e q}-C_{g a s, i}\right)\left(\frac{\kappa_{o r g-g a s, i} \cdot A}{V_{o r g}}\right)
\end{gathered}
$$

241 where $C_{p, i}[\mathrm{M}]$ and $C_{p, i}^{e q}[\mathrm{M}]$ are the concentration and equilibrium concentration of compound $i$ in

242 phase $p, \kappa_{\text {org-aq, } i}\left[\mathrm{dm} \mathrm{s}^{-1}\right]$ and $\kappa_{\text {org-gas, }, i}\left[\mathrm{dm} \mathrm{s}^{-1}\right]$ are the mass transfer coefficients for compound $i$, and $243 A\left[\mathrm{dm}^{2}\right]$ is the cross-sectional area of the phase interface. Mass transfer coefficients can be found in 244 Table S2.

\subsubsection{Sample Removal}

246 Sample removal and re-equilibration of PCE, TCE, and hydrogen was also included in the model.

247 Sampling removes substrate from the system, and it has previously been found to increase the 248 chloride concentration in the aqueous phase above what would have been possible without removal 249 of the aqueous phase (Buttet et al., 2018). Additionally, removal of phase volume from the system 250 affects the pressure in the batch bottle. Equilibration of the volatile compounds was modeled as 251 occurring instantaneously after sample removal. The total moles of the compound remaining in the 252 system at time $t$, after sample removal, was calculated by subtracting the moles in the aqueous 253 sample removed at time $t$ from the moles present before removal at time $t-1$ :

$$
n_{i, t}=\left(C_{g a s, i} V_{g a s}+C_{\text {org }, i} V_{\text {org }}+C_{a q, i} V_{a q}\right)_{t-1}-\left(C_{a q, i} V_{S, a q}\right)_{t}
$$

254 where $n_{i, t}[\mathrm{~mol}]$ is the remaining mass of compound $i$ and $V_{S, a q}[\mathrm{~L}]$ is the volume of the removed 255 sample. The concentrations of the compound in each phase after sample removal was then 256 calculated (Buchner et al., 2016) using the partition coefficients $K_{\text {gas-org }}$ and $K_{\text {org-aq }}$ [-] (Table S2). 
259 The iron and sulfide chemistry in the aqueous phase both affects and is affected by the microbial

260 reduction processes. The aqueous chemistry directly affects these bacterial processes via the

261 speciation, and consequently the bioavailability, of the Fe(III) electron acceptor (Haas and

262 Dichristina, 2002; Liu et al., 2001). Both the SRB and FeRB were modeled as only able to respire

263 aqueous $\mathrm{Fe}(\mathrm{III})$ ions and the $\mathrm{Fe}(\mathrm{III})$ hydroxyl complexes $\mathrm{Fe}(\mathrm{OH})_{3}, \mathrm{Fe}(\mathrm{OH})_{2}{ }^{+}$, and $\mathrm{Fe}(\mathrm{OH})_{4}{ }^{-} . \mathrm{Fe}(\mathrm{III})$

264 was added to the media as Fe(III)-citrate, which was modeled in PHREEQC to speciate according

265 to the reactions included in Table 2.

Table 2. Fe(III)-citrate speciation reactions included in the PHREEQC database

\begin{tabular}{|c|c|}
\hline Reaction & $\log (k)$ \\
\hline $\mathrm{Fe}^{3+}+$ Citrate $^{3-}+\mathrm{H}_{2} \mathrm{O} \rightarrow \mathrm{FeCitrateOH}^{-}+\mathrm{H}^{+}$ & $9.98^{\mathrm{a}}$ \\
\hline $\mathrm{Fe}^{3+}+$ Citrate $^{3-} \rightarrow$ FeCitrate & $12.55^{\mathrm{b}}$ \\
\hline $\mathrm{Fe}^{3+}+2$ Citrate $^{3-}+\mathrm{H}_{2} \mathrm{O} \rightarrow$ FeCitrate $_{2} \mathrm{OH}^{4-}+\mathrm{H}^{+}$ & $13.42^{\mathrm{a}}$ \\
\hline $\mathrm{Fe}^{3+}+$ Citrate $^{3-}+\mathrm{H}^{+} \rightarrow \mathrm{FeCitrateH}^{+}$ & $19.8^{\mathrm{b}}$ \\
\hline $\mathrm{Fe}^{3+}+2$ Citrate $^{3-}+2 \mathrm{H}^{+} \rightarrow$ FeCitrate $_{2} \mathrm{H}_{2}^{-}$ & $26.46^{\mathrm{a}}$ \\
\hline
\end{tabular}

269 Geochemical reactions in the system, depicted in Figure 1 as dotted lines, are also driven by the

270 bacterial processes. Fe(III) reacts abiotically with sulfide, a product of sulfate reduction, by the

271 stoichiometric reaction and rate kinetics described in Equations 11 and 12, respectively:

$$
\begin{aligned}
& 2 \mathrm{Fe}^{3+}+H S^{-} \rightarrow 2 \mathrm{Fe}^{2+}+S^{0}+H^{+} \\
& \frac{d C_{F e(I I)}}{d t}=k_{F e A b i o} C_{F e(I I I)} C_{S(-I I)} 0.5
\end{aligned}
$$

272 where $k_{\text {FeAbio }}\left[\mathrm{L}^{0.5} \mathrm{~mol}^{-0.5} \mathrm{~s}^{-1}\right]$ is the kinetic rate constant for $\mathrm{Fe}(\mathrm{II})$ production as a result of abiotic

273 Fe(III) reduction (Poulton et al., 2004; Rickard and Luther, 2007). The rate of abiotic Fe(III)

274 reduction has been determined to be first order with respect to $\mathrm{Fe}(\mathrm{III})$ and 0.5 order with respect to 
sulfide (Poulton et al., 2004). The produced Fe(II) then also reacts with sulfide to form amorphous $\mathrm{FeS}_{(\mathrm{s})}$ that later crystalizes to mackinawite (Remoundaki et al., 2008; Zhou et al., 2017, 2014). is formed via the intermediate $\mathrm{Fe}(\mathrm{HS})_{2(\mathrm{~s})}$ mineral with an empirically determined pseudo first-order sulfide disappearance rate of $15 \mathrm{~s}^{-1}$ (Rickard, 1995). Because the formation of the FeS precipitate is quick and the duration of the experiment was not long enough for crystalized mackinawite to form, amorphous $\mathrm{FeS}_{(\mathrm{s})}$ was allowed to precipitate in the model at equilibrium via the reaction (Jakobsen, 2007):

$$
\mathrm{Fe}^{2+}+\mathrm{HS}^{-} \rightarrow \mathrm{FeS}_{(s)}+\mathrm{H}^{+}
$$

284 where the $\log$ of the equilibrium constant, $\log (\mathrm{k})$, for $\mathrm{FeS}_{(\mathrm{s})}$ was used from the PHREEQC 285 geochemical database.

\subsubsection{Coupling Strategy}

287 The bacterial, mass transfer, consecutive sample removal, and aqueous chemistry modeling 288 components are linked together via the scheme presented in Figure 2. Two software platforms are 289 used, MATLAB ${ }^{\circledR}$ (R2017b) and PHREEQC-3 (Parkhurst and Appelo, 2013). The IPhreeqc module 290 (Charlton and Parkhurst, 2011), allowing the use of PHREEQC with other codes and scripting 291 languages (Muniruzzaman and Rolle, 2016; Van Breukelen et al., 2017; Wissmeier and Barry, 292 2011), was employed to interface the two software platforms. The mass transfer processes and re293 equilibration after sample removal were performed in MATLAB ${ }^{\circledR}$, analogous to the transport steps 294 in reactive transport models using an operator splitting approach (e.g., Muniruzzaman and Rolle, 295 2016; Rolle et al., 2018). The state of the aqueous phase after these processes was then 296 communicated to the PHREEQC geochemical code using the IPhreeqc module. All biogeochemical 
processes including aqueous speciation, homogeneous and heterogeneous reactions, contaminant degradation and bacterial population dynamics were performed by PHREEQC. The flexible coupling strategy allowed us to perform simulations mimicking the steps taken in the laboratory experiments, as illustrated in Figure 2. First, the media was assembled and the volatile compounds equilibrated between all phases (Point A). The bacterial inocula were then added to each experimental batch (Point B), and an initial sample was removed and the volatile compounds reequilibrated (Point C).

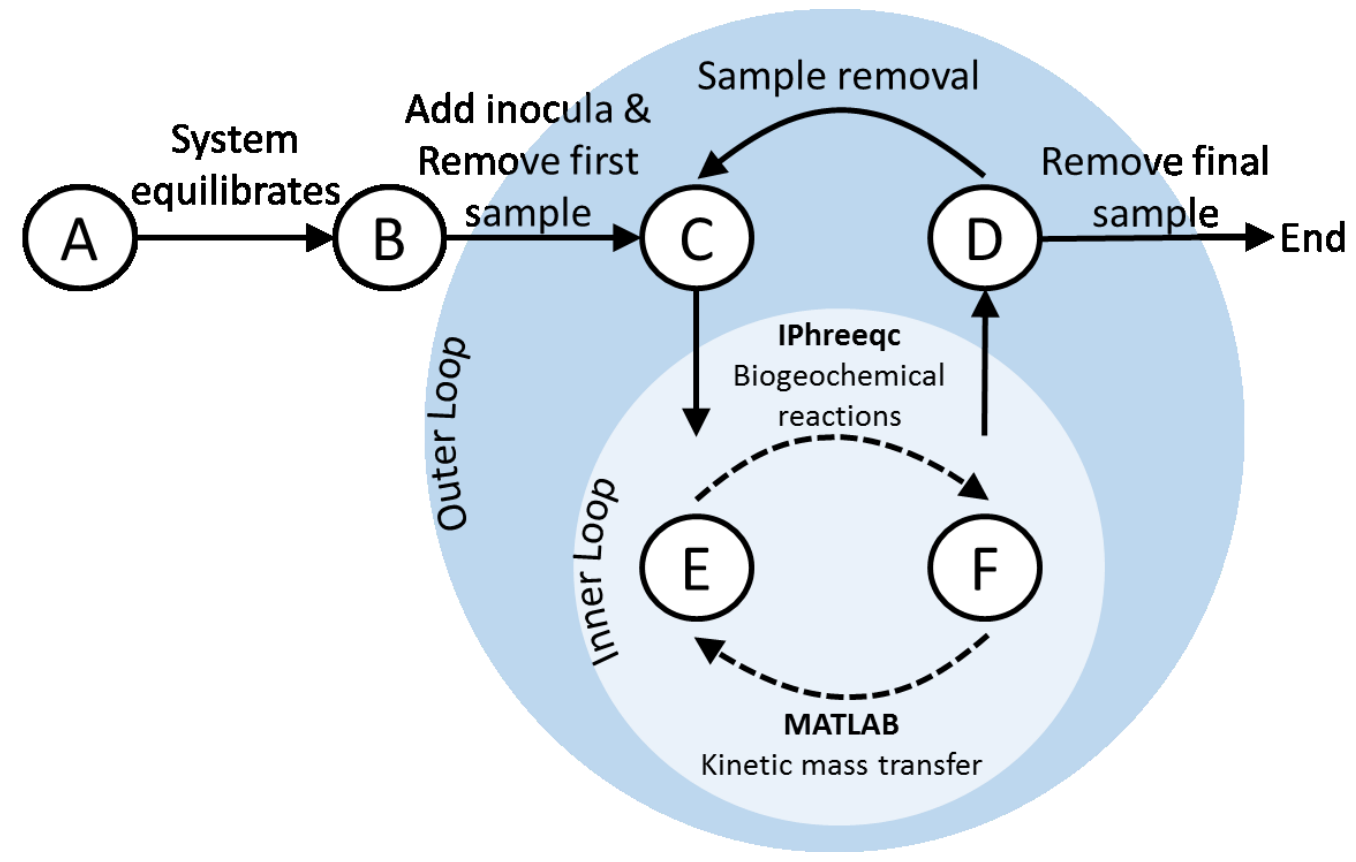

Figure 2. Coupling strategey for MATLAB ${ }^{\circledR}$ and PHREEQC software platforms; the bacterial and aqueous chemical procceses are computed using PHREEQC and the instantaneous and kinetic mass transfer processes are completed using MATLAB ${ }^{\circledR}$. Solid black arrows denote steps that are modeled to occur instantaneously, and dashed arrows denote continuous processes that proceed for a defined time length.

310 Equilibration after the initial sample is removed begins the outer of two nested loops. The outer 311 loop is organized in discrete segments, the length of which is defined by the time between the 
experimental sampling events. Point $\mathrm{D}$ is prior to and Point $\mathrm{C}$ is directly after sample removal. To

313 move from Point $\mathrm{C}$ to $\mathrm{D}$, the model enters the inner of the two nested loops. To return to Point $\mathrm{C}$

314 from Point D, the volume of the aqueous phase is decreased by the size of the sample volume and

315 the volatile compounds are re-equilibrated between the phases.

316 After a sample is removed, the inner of the two nested loops begins. This inner loop is based on an 317 operator splitting scheme that alternates between the PHREEQC and MATLAB ${ }^{\circledR}$ platforms with a 318 small coupling time step (i.e., $\Delta \mathrm{t}=5 \mathrm{~s}$ ). To move from Point $\mathrm{E}$ to $\mathrm{F}$, the bacterial and geochemical 319 processes proceed in PHREEQC. After each time step, the model arrives to Point F, and the 320 concentrations of the volatile compounds in the aqueous phase are passed to MATLAB ${ }^{\circledR}$, which 321 solves the set of differential equations to describe kinetic mass transfer between the phases with the 322 stiff solver ode15s. The concentrations of the volatile compounds are returned to PHREEQC at 323 Point E and the loop repeats. When the next sample is to be removed, the concentrations of the 324 volatile compounds at Point $\mathrm{F}$ are returned to MATLAB ${ }^{\circledR}$ at Point $\mathrm{D}$, a sample is removed, and the 325 next iteration of the outer loop begins at Point C. Removal of the last sample signals the end of the 326 outer loop.

\subsubsection{Parameter Fitting}

328 The model was applied to the performed experiments to interpret the chemical and molecular data 329 in all the experimental batch setups that we have considered with the aim of quantifying the kinetics 330 of the different microbial guilds. As many parameters were chosen from the literature as possible to 331 limit the number of parameters to be fitted to the $k_{\max }$ for each guild's respiration process. Parameter 332 fitting was conducted within the $\mathrm{MATLAB}^{\circledR}$ environment using the function lsqnonlin (e.g., 333 Haberer et al., 2015). The OHRB initial cell count was fitted for each experimental batch to account 334 for unknown activity of the inoculum, in which the upper bound was the measured initial count, $3351.02 \times 10^{8}$ cells $\mathrm{L}^{-1} . k_{\max }$ was fitted for all bacterial guilds in all experimental batches. In the batch 
that included $\mathrm{OHRB}$ and $\mathrm{FeRB}, K_{S, F e R B, F e 3}$ was also fitted, as values found in the literature were for 337 the total dissolved Fe(III) concentration, not the easily bioavailable dissolved Fe(III) concentration 338 (Liu et al., 2001). Parameters fit to describe 2-part community batch configurations, e.g., $K_{S, F e R B, F e 3}$ 339 and $k_{\text {FeAbio }}$, were used as fixed inputs in subsequent, 3-part community batch simulations.

\section{Results and Discussion}

341 The four experimental configurations are detailed in Table 3. From left to right, each column gives 342 the details of the batches as they increase in complexity. Batch 1, the single-community consisting 343 of the OHRB consortium, is used to demonstrate the utility of the model as it relates to mass 344 transfer across the phase boundaries and replicating sequential sample removal. Batch 2, the 345 community consisting of OHRB and FeRB, shows how multiple guilds can be simulated. Aqueous 346 speciation is modeled in all batches, and Batch 2 demonstrates that the Fe(III) bioavailability 347 directly impacts iron respiration. Batch 3 is still comprised of two guilds, OHRB and SRB, and 348 includes the complex aquatic geochemical processes that result from sulfate reduction products.

349 Finally, Batch 4 is the most complex configuration, and consists of all three guilds and 350 biogeochemical reactions considered. Data and simulations for each batch duplicate are included in 351 the SI. In all simulations, the fitted initial cell count was found to vary in an interval spanning less 352 than half an order of magnitude (i.e., with a minimum of $5.93 \times 10^{7}$ cells $\mathrm{L}^{-1}$ ), indicating the added 353 cultures were proportionally and initially active. 


\begin{tabular}{|c|c|c|c|c|}
\hline & $\begin{array}{c}\text { Single } \\
\text { Community }\end{array}$ & \multicolumn{2}{|c|}{$\begin{array}{c}\text { Two-part } \\
\text { Community }\end{array}$} & $\begin{array}{l}\text { Three-part } \\
\text { Community }\end{array}$ \\
\hline Batch & 1 & 2 & 3 & 4 \\
\hline Guilds & OHRB & $\begin{array}{l}\text { OHRB } \\
\text { FeRB }\end{array}$ & $\begin{array}{l}\text { OHRB } \\
\text { SRB }\end{array}$ & $\begin{array}{l}\text { OHRB } \\
\text { FeRB } \\
\text { SRB } \\
\end{array}$ \\
\hline 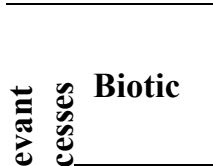 & PCE reduction & $\begin{array}{l}\text { PCE reduction } \\
\text { Fe(III) reduction }(F e R B)\end{array}$ & $\begin{array}{l}\text { PCE reduction } \\
\text { Sulfate reduction } \\
\text { Fe(III) reduction (SRB) }\end{array}$ & $\begin{array}{l}\text { PCE reduction } \\
\text { Fe(III) reduction }(\mathrm{FeRB}) \\
\text { Sulfate reduction } \\
\text { Fe(III) reduction }(\mathrm{SRB})\end{array}$ \\
\hline Abiotic & & $\mathrm{Fe}(\mathrm{III})$ speciation & $\begin{array}{l}\mathrm{Fe}(\mathrm{III}) \text { speciation } \\
\mathrm{Fe}(\mathrm{III}) \text { reduction } \\
\mathrm{FeS}_{(\mathrm{s})} \text { precipitation }\end{array}$ & $\begin{array}{l}\mathrm{Fe}(\mathrm{III}) \text { speciation } \\
\mathrm{Fe}(\mathrm{III}) \text { reduction } \\
\mathrm{FeS}_{(\mathrm{s})} \text { precipitation }\end{array}$ \\
\hline $\begin{array}{l}\text { Relevant } \\
\text { Data }\end{array}$ & Chloride & $\begin{array}{l}\text { Chloride } \\
\text { Fe(II) } \\
\text { T-RFLP }\end{array}$ & $\begin{array}{l}\text { Chloride } \\
\text { Fe(II) } \\
\text { T-RFLP } \\
\text { Sulfate } \\
\end{array}$ & $\begin{array}{l}\text { Chloride } \\
\text { Fe(II) } \\
\text { T-RFLP } \\
\text { Sulfate }\end{array}$ \\
\hline
\end{tabular}

\subsection{Single Community: Organohalide-Respiring Bacteria}

358 In Batch 1, the OHRB consortium was cultivated without any other functional guild, and thus the 359 chloride data is most relevant, as it is the product of PCE respiration. Repeated chloride 360 concentration values from approximately $48 \mathrm{~h}$ indicate that all PCE consumption stopped at this 361 time. The model was able to simulate the sigmoid curve of the measured chloride (Figure 3a) and 362 thus capture PCE dechlorination to TCE and subsequent growth of OHRB. The $\mathrm{k}_{\max , P C E}$ for the 363 OHRB in Batch 1 and its biological duplicate were $4.50 \times 10^{-18}$ and $4.01 \times 10^{-18}$ mol $_{\mathrm{PCE}} \mathrm{cell}^{-1} \mathrm{~s}^{-1}$ 364 (Table 4), which is one order of magnitude greater than the average value found during previous experiments with the same consortium (Buttet et al., 2018) and also in other studies with members of the same organohalide-respiring genus (Aeppli et al., 2009; Scholz-Muramatsu et al., 1995). This

367 can be attributed to the difference of electron donor, as formate was used as the electron donor in 368 Buttet et al. (2018), and supply of hydrogen has been shown to best promote dechlorination 369 (Aulenta et al., 2007). 
(a)

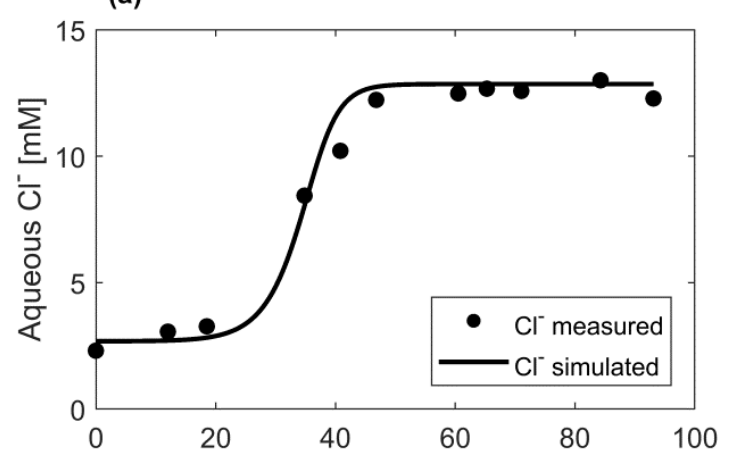

(b)

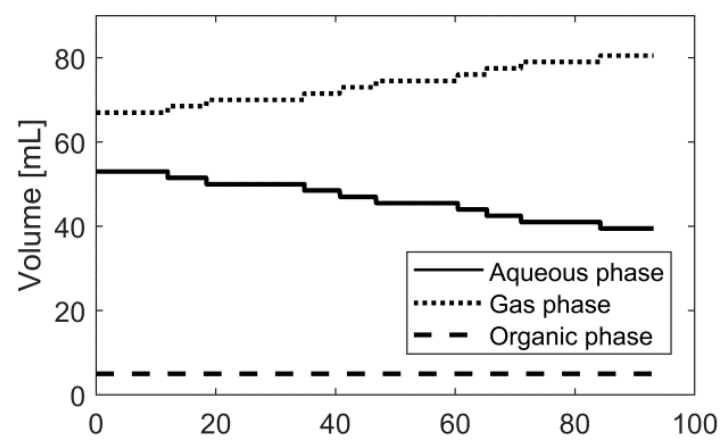

(c)

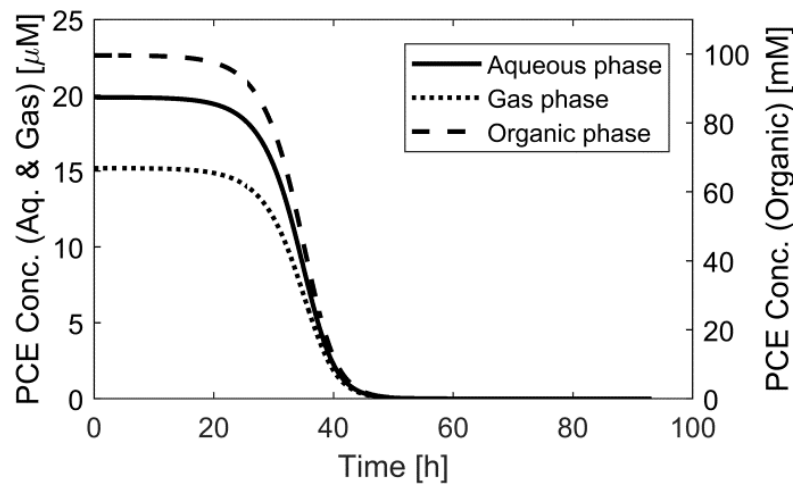

371 Figure 3. OHRB only (Batch 1) experimental and simulated chloride aqueous concentration (a),

372 phase volume changes due to sampling (b), and simulated decrease of PCE in all phases (c). Data

373 and simulation results for the biological duplicate are included in the Supplementary Information

374 (Figure S1).

375 Figure $3 \mathrm{~b}$ depicts the calculated volume of each phase throughout the experiment. Even with a

376 minimal sampling volume of $1.5 \mathrm{~mL}$, it is still evident that consecutive sampling has a considerable

377 impact on the phase volumes of the batch system. The initial volume of the aqueous phase 
378 decreased by $18 \%$ (and the volume of the gas phase increased by the same volume) over the

379 duration of the experiment. The initial pressure in the bottle was approximately $1.5 \mathrm{~atm}$, determined

380 when the headspace was exchanged prior to addition of the organic phase during preparation of the 381 experiment. At the end of the experiment, because of sample removal and consumption of PCE and 382 hydrogen, the calculated pressure in the batch was $1.0 \mathrm{~atm}$. Additionally, the model allows us to 383 track the evolution of the volatile species in all phases (Figure 3c, example for PCE). It was 384 determined that the electron donor was present in excess in the aqueous phase; the lowest aqueous 385 hydrogen concentration in the batch was $5.35 \times 10^{-4} \mathrm{M}$. The model shows that the PCE concentration 386 in all three phases is zero after approximately $48 \mathrm{~h}$. This coincides with the repeated chloride 387 concentration values and simulation (Figure 3a) that indicate PCE respiration has stopped, with 388 complete PCE consumption in the system after $48 \mathrm{~h}$.

\subsection{Two-Part Community: Organohalide- and Fe(III)-Respiring Bacteria}

390 In Batch 2, the two-part community composed of the OHRB consortium and FeRB (Table 3

391 Column 2), chloride and Fe(II) are respiration products that can be used as evidence of the

392 functional guilds' metabolic activity. The chloride sigmoid data and simulation for Batch 2 is 393 similar to Batch 1, with the OHRB alone, and repeated chloride concentration values were also 394 observed after approximately 48 h. (Figure 4a). 
(a)

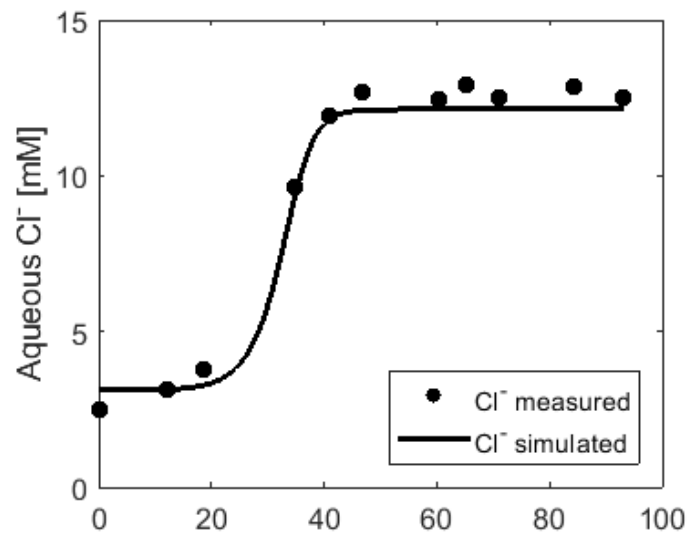

(b)

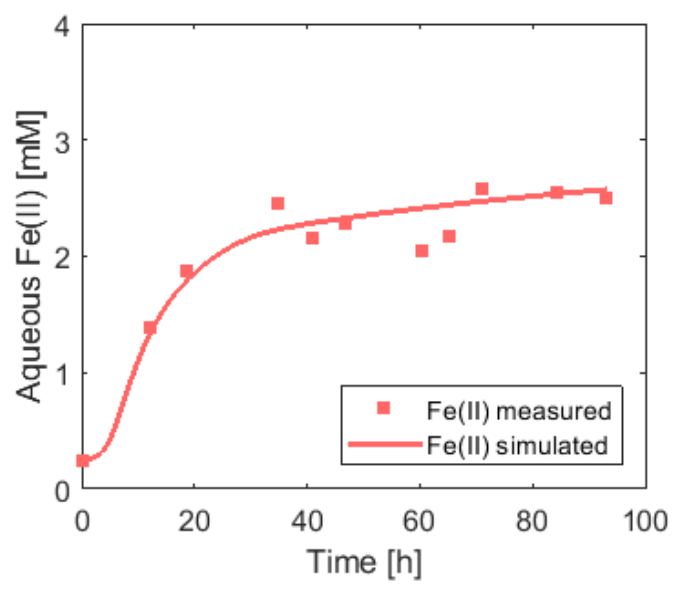

(c)

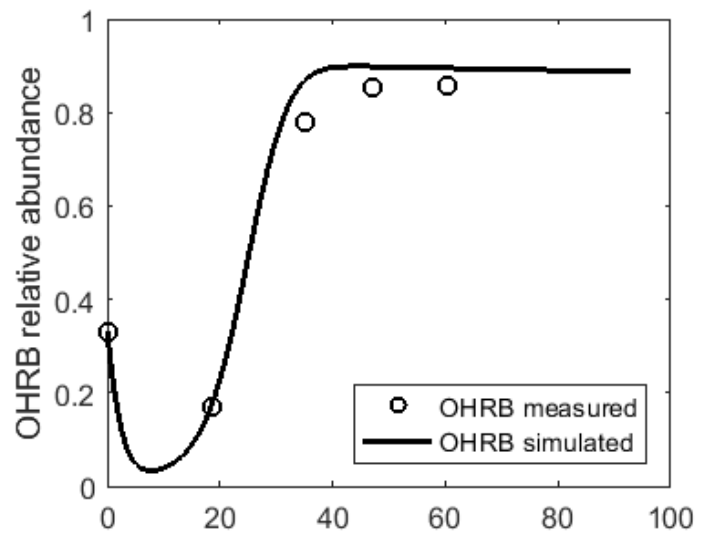

(d)

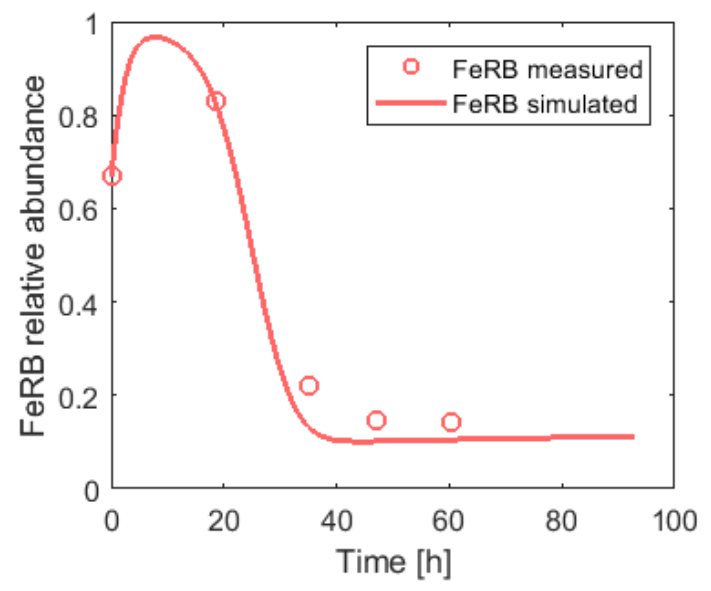

Figure 4. OHRB and FeRB (Batch 2) experimental and simulated chloride and Fe(II) aqueous concentrations ( $a$ and $b$ ) and $O H R B$ and $F e R B$ relative abundance ( $c$ and $d$ ). Data and simulation results for the biological duplicate are included in the Supplementary Information (Figure S2).

The Fe(II) concentration increases rapidly within the first $24 \mathrm{~h}$ of the experiment, and then increases

400 slowly throughout the rest of the experimental duration (Figure 4b). The concentration of Fe(II)

401 obtained at approximately $48 \mathrm{~h}$, when PCE reduction was complete, is less than the Fe(III)

402 concentration added as Fe(III)-citrate because of Fe(III) speciation in the medium. Fe(II) reduction 403 is still ongoing at this time, since after the initial equilibration of the solution, less than $4 \%$ of the $404 \mathrm{Fe}(\mathrm{III})$ was in a form that could be used by the bacteria. This phenomena has previously been 405 observed in experiments using a related bacterial strain (Shewanella putrefaciens strain CN32), in 


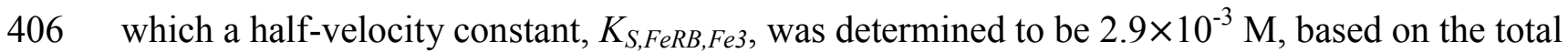
$407 \mathrm{Fe}(\mathrm{III})$ concentration and with lactate as the electron donor and carbon source (Liu et al., 2001). The $408 K_{S, F e R B, F e 3}$ fit to our experiment were found to be $7.93 \times 10^{-5}$ and $7.26 \times 10^{-5} \mathrm{M}$ in Batch 2 and its 409 biological duplicate. These values are two orders of magnitude lower, which is consistent with the 410 difference in magnitude between the bioavailable (this study) and total (Liu et al., 2001) 411 concentrations of the electron acceptor.

412 Because this batch includes multiple community members, the T-RFLP data shows the change in 413 the community over the duration of the experiment. Figure $4 \mathrm{c}$ and Figure $4 \mathrm{~d}$ show that the FeRB 414 dominate the community for the first $24 \mathrm{~h}$ of the experiment, and the OHRB dominate throughout 415 the rest of the experimental duration. This correlates well with the rapid FeRB growth in the first 24 $416 \mathrm{~h}$ of the experiment and the rapid OHRB growth between 24 and $40 \mathrm{~h}$ of the experiment. The 417 model, including the dynamics of the OHRB and FeRB, could well capture the observed molecular 418 data and the shift in dominance between the two microbial guilds during the timeframe of the 419 experiment.

\subsection{Two-Part Community: Organohalide- and Sulfate-Respiring Bacteria}

421 Batch 3, the two-part community that contained OHRB and SRB (Table 3 Column 3), inherently contained more processes than the previous batches; the selected SRB bacteria is metabolically versatile and the products from sulfate reduction react with $\mathrm{Fe}(\mathrm{III})$ and $\mathrm{Fe}(\mathrm{II})$. The model was again able to simulate the sigmoid chloride accumulation curve (Figure 5a), and in this batch, repeated chloride concentration values were obtained after approximately $60 \mathrm{~h}$. The sulfate concentration (Figure 5b) decreases slowly for the first $60 \mathrm{~h}$ of the experiment before decreasing rapidly between approximately 60 and $65 \mathrm{~h}$. This sulfate consumption by the SRB is reproduced well using the

428 kinetic constants determined by previous experiments (Noguera et al., 1998) that used hydrogen as an electron donor. The relative abundance data (Figure 5d and Figure 5e) show that OHRB steadily 
430 become dominant throughout the duration of the experiment. The simulation of the relative 431 abundance data captures the general trend, in particular the repeated data points at the end of the T432 RFLP time series data, which indicates that the model is able to capture the relative growth of the 433 two guilds based on their yields once their electron acceptors have been completely consumed. 
(a)

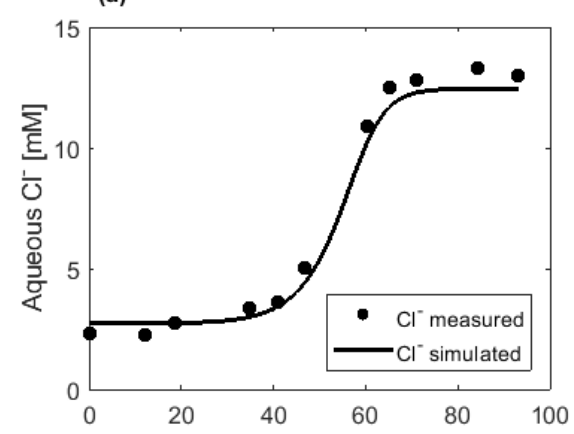

(b)

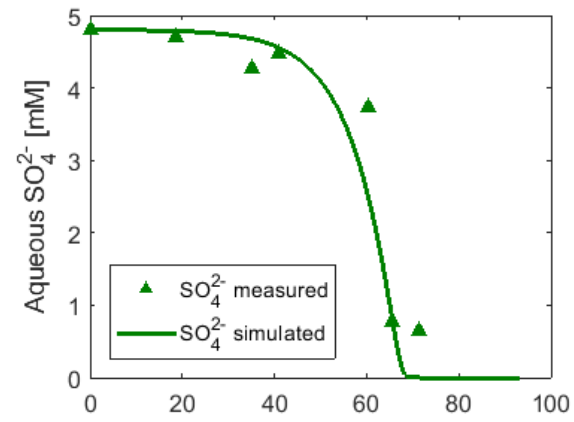

(c)

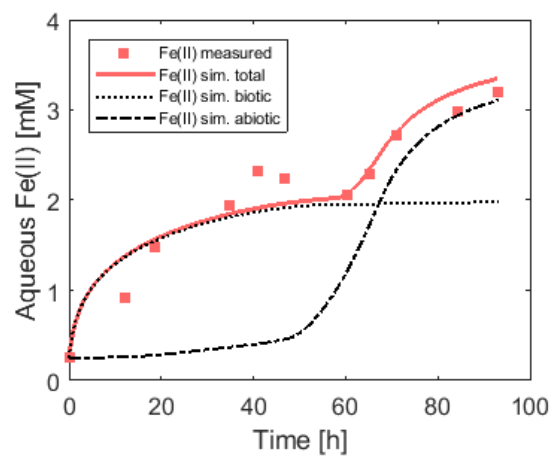

(d)

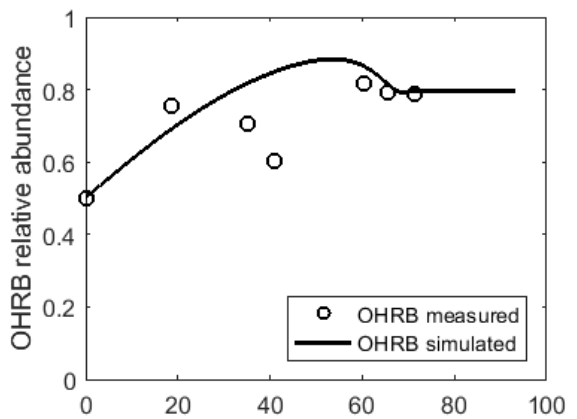

(e)

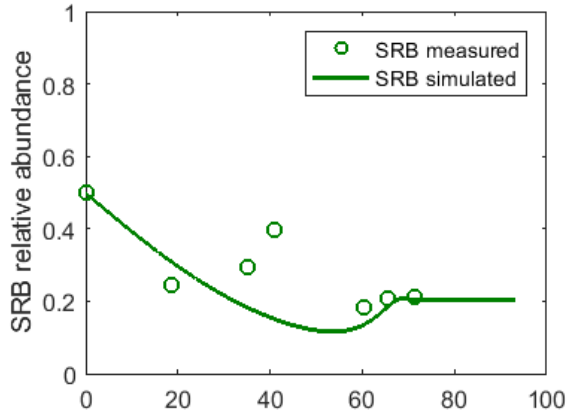

(f)

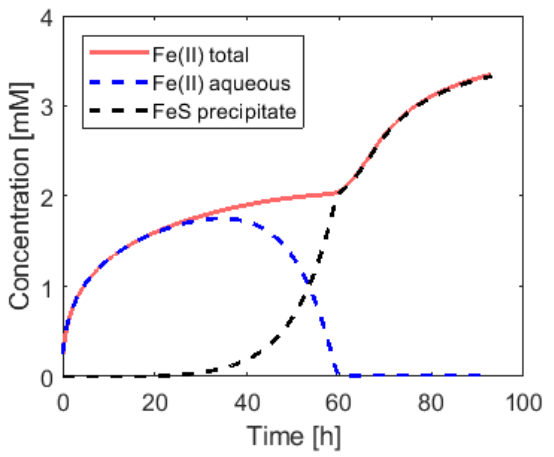

435 Figure 5. OHRB and SRB (Batch 3) experimental and simulated chloride and sulfate aqueous

436 concentrations ( $a$ and b); experimental and simulated OHRB and SRB relative abundance (d and

437 e); experimental Fe(II) measurements and total simulated Fe(II)(red line), Fe(II) contributed by the

438 biotic reduction process by SRB (black dotted line), and the Fe(II) contributed by abiotic reduction

439 of Fe(III) by sulfide (black dashed line)(c); and simulated aqueous Fe(II) concentration (blue line)

440 and amorphous $\mathrm{FeS}_{(s)}$ concentration (dashed black line)(f). Data and simulation results for the

441 biological duplicate are included in the Supplementary Information (Figure S3). 
The Fe(II) concentration measurements in Batch 3 (Figure 5c) appears to show two periods of fast accumulation, the first within $0-20 \mathrm{~h}$ and the second within $60-70 \mathrm{~h}$. This is in contrast to the Fe(II) accumulation curve that results from Fe(III) respiration from FeRB in Batch 2 (Figure 4b), which only showed an initial concentration increase in the first $24 \mathrm{~h}$. In Batch 3, both biotic and abiotic $\mathrm{Fe}(\mathrm{III})$ reduction to $\mathrm{Fe}(\mathrm{II})$ take place, and each process accounts for one of these observed increases. Figure 5c demonstrates how neither abiotic nor biotic Fe(III) reduction alone is able to account for the measured $\mathrm{Fe}(\mathrm{II})$ concentration, and that the Fe(II) accumulation curve is a composite of two $\mathrm{Fe}(\mathrm{III})$ reduction processes. During the first $18 \mathrm{~h}$ of the experiment, the Fe(II) concentration has risen by $1.2 \mathrm{mM}$ and the sulfate concentration has decreased by $0.1 \mathrm{mM}$. Since 2 moles of Fe(II) are produced per mole of sulfide consumed during abiotic Fe(III) reduction (Equation 11), another process must be responsible for the observed increase in Fe(II). Likewise, if only first-order biotic

$453 \mathrm{Fe}(\mathrm{III})$ reduction by SRB is included in the model, then the elevated Fe(II) measurements at the end of the time series are unable to be captured.

The SRB used in this experiment is capable of both $\mathrm{Fe}(\mathrm{III})$ and sulfate reduction. Biotic degradation of Fe(III) by Desulfovibrio sp. has been documented to not result in cell synthesis and can be modeled as a first-order process dependent on the concentration of bioavailable Fe(III) (Elias et al., 2004). It has been posited that Desulfovibrio sp. reduce Fe(III) because it is a more favorable electron acceptor (Zhou et al., 2017) or as protection against cell oxidation by compounds with a 460 higher redox potential than that of sulfate (Cypionka, 2000; Elias et al., 2004). Regardless of the 461 objective, it is evident that Fe(III) reduction proceeds first, followed by an apparent acceleration of 462 sulfate reduction after approximately $60 \mathrm{~h}$.

463 The model also allows the simulation of the chemical reactions that occur as a result of sulfide 464 production via SRB respiration (Figure 5f). Though only the total Fe(II) concentration was 465 quantified, the formation of black precipitate in those batches that contained SRB was observed 
466 after $24 \mathrm{~h}$. The formation of precipitate was simulated using the standard thermodynamic

467 PHREEQC database; the model corroborates what is visually observed and also shows that

468 amorphous mackinawite, or $\mathrm{FeS}_{(\mathrm{s})}$, begins to form after approximately $20 \mathrm{~h}$. The simulation of

469 Batch 3 shows that although sulfate reduction does occur relatively slowly throughout the first $40 \mathrm{~h}$

470 of the experiment (Figure $5 \mathrm{~b}$ ), $\mathrm{FeS}_{(\mathrm{s})}$ is not the primary form of $\mathrm{Fe}(\mathrm{II})$ until after approximately $60 \mathrm{~h}$

471 of SRB growth. When sulfate is nearly depleted, all measured $\mathrm{Fe}(\mathrm{II})$ is bound as $\mathrm{FeS}_{(\mathrm{s})}$.

\subsection{Three-Part Community: Organohalide-, Fe(III)-, and Sulfate-Respiring Bacteria}

473 In Batch 4, all three guilds were cultivated together (Table 3 Column 4), and all processes that were 474 observed in each previous batch occurred together. The inoculum for this batch was comprised of 475 the three guilds such that the initial cell count of each guild was the same as in the other three 476 batches. Even when all three guilds are present, electron donor is still supplied in excess, and the 477 lowest aqueous hydrogen concentration was $2.31 \times 10^{-4} \mathrm{M}$.

478 The sigmoid chloride accumulation curve in Batch 4 (Figure 6a) is similar to those in Batches 1 479 (Figure 3a) and 2 (Figure 4a), as repeated concentration values were observed after approximately 48048 hours. The Fe(II) measurements (Figure 6c) are similar to those found in Batch 3 (Figure 5c), in 481 that there is a relatively fast increase to a concentration of about $2 \mathrm{mM}$ within the first $20 \mathrm{~h}$, and a 482 second relatively fast increase in concentration at about $60 \mathrm{~h}$. The sulfate curve, however, is slightly 483 different in Batch 4 (Figure 6b) than in Batch 3 (Figure 5b). Although the sulfate disappears from 484 the experiment at approximately $70 \mathrm{~h}$ in both batches, the decrease in measured sulfate appears to 485 begin earlier and is more gradual in Batch 4 than in Batch 3. The model is able to accurately 486 simulate both the chloride and sulfate curves as well as the Fe(II) composite curve. 
(a)

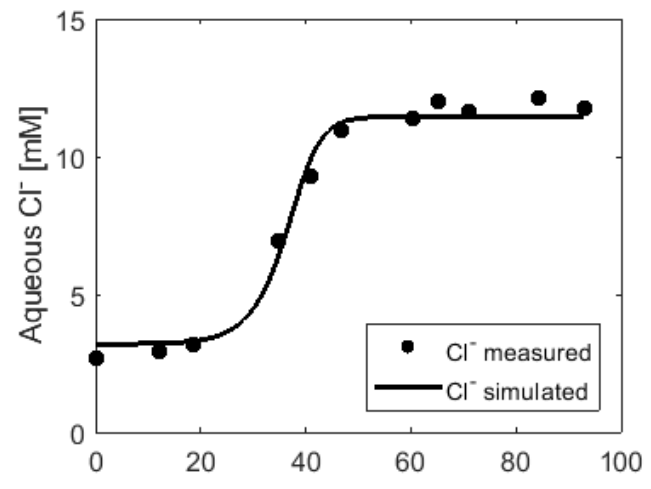

(b)

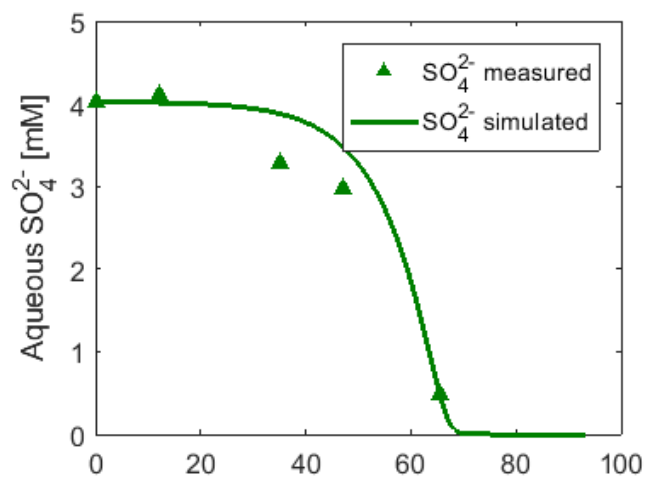

(c)

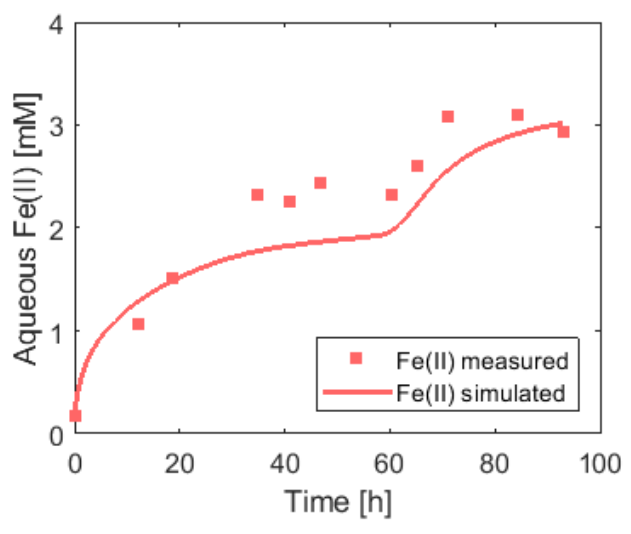

(d)

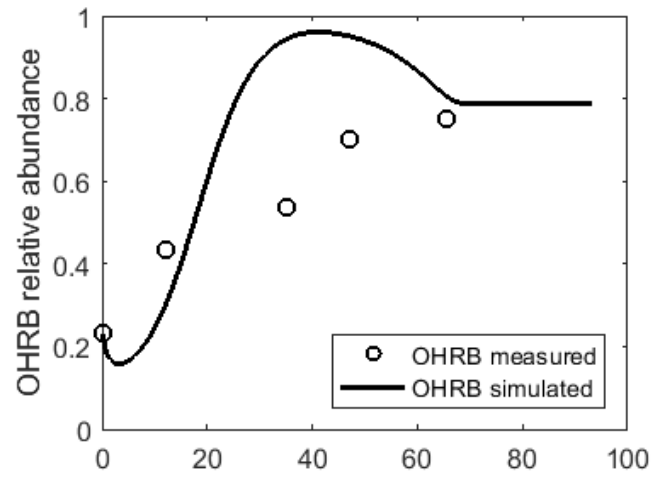

(e)
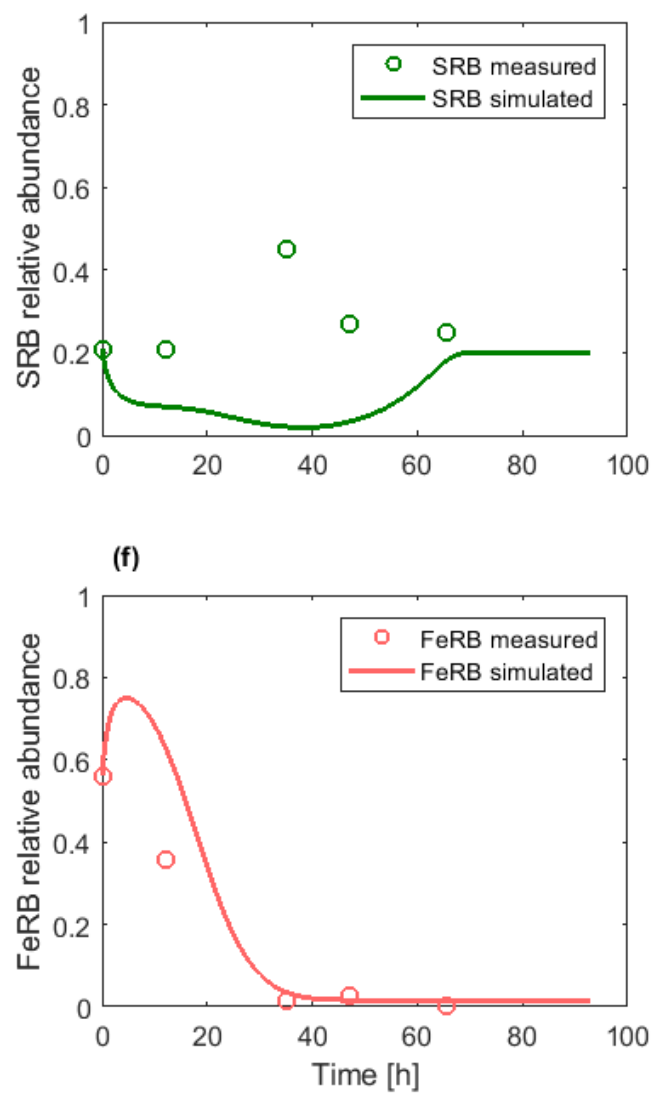

488 Figure 6. OHRB, SRB, and FeRB (Batch 4) experimental and simulated chloride, sulfate, and total $489 \mathrm{Fe}(\mathrm{II})$ aqueous concentrations ( $a, b$, and c) and OHRB, SRB, and FeRB relative abundance (d, e, 490 and f). Data and simulation results for the biological duplicate are included in the Supplementary 491 Information (Figure S4). 
The T-RFLP relative abundance data show that the OHRB gradually grow to dominate the 511 simulated decrease of sulfate.

\subsection{Respiration Rates} microbial community throughout the time series while the SRB maintain a more or less steady proportion and the FeRB rapidly decline to become a small proportion of the community. Just as in Batches 2 and 3, the proportional community measurements (Figure $6 \mathrm{~d}$, e, and $\mathrm{f}$ ) at the end of the time series, after approximately $65 \mathrm{~h}$, are captured for all three guilds, which is consistent with the yield factors of the different guilds. More difficulties were encountered in the simulation of the transient measurements of the community development. The model allows capturing the decrease of FeRB, but overestimates the transient relative abundance for OHRB and underestimates for SRB. This discrepancy may be because of the relative nature of the measurements that entails higher uncertainties in this complex setup where all three guilds are simultaneously present (i.e., if one measurement is inaccurate the others are affected), or it may indicate a process or metabolic complementarity that is not represented in the current model formulation. It is evident from the relative abundance data in Figure $6 \mathrm{f}$ that the FeRB do not thrive in relation to the other guilds in this three guild scenario. It is possible that, in contrast to Batch 2, the consumption of the bioavailable $\mathrm{Fe}(\mathrm{III})$ by the SRB and abiotic reduction is too great to allow the FeRB to access their electron acceptor. However a change in the sulfate curve (Figure 6b) from Batch 3 (Figure 5b) is apparent, in that the concentration decreases earlier in the experiment and more gradually. The Fe(III) consumption by the FeRB, although not sufficient to allow FeRB to compete with the other guilds, was enough to allow sulfate reduction by SRB to occur earlier, as evidenced by the observed and

Investigating the batches comprehensively can yield knowledge about the way that $\mathrm{Fe}(\mathrm{III})$ and sulfate reduction impact PCE degradation. Table 4 details the inverse fitting results for each batch and its duplicate. All of the fitted $k_{\max }$ parameters for each guild and electron acceptor are within the 
same order of magnitude, and it may appear that the bacteria behave similarly regardless of the community configuration. However, a visual comparison of the electron acceptor consumption rate

518 can further illuminate how the community configuration impacts PCE degradation. In Figure 7, the 519 rate of consumption of each electron acceptor in each batch configuration is displayed graphically. 520 The highest point of each peak is the location of the maximum rate of consumption, and a narrow 521 peak indicates a smaller time frame of respiration whereas a broader peak indicates respiration of 522 the electron acceptor was sustained over a longer time.

523 Table 4. Fitted parameter model results. Estimated parameters for each batch duplicates are given 524 in the second row for each batch; data and simulations for duplicates are included in the SI.

\begin{tabular}{|c|c|c|c|c|c|c|c|}
\hline \multicolumn{2}{|c|}{ Parameter } & $\begin{array}{l}\boldsymbol{k}_{\max , \boldsymbol{O H R B}} \\
\text { mol }_{\mathrm{PCE}} \operatorname{cell}^{-1} \mathrm{~s}^{-1}\end{array}$ & $\begin{array}{l}\boldsymbol{k}_{\boldsymbol{m a x}, \boldsymbol{F e R B}} \\
\mathrm{mol}_{\mathrm{Fe} 3} \operatorname{cell}^{-1} \mathrm{~s}^{-1}\end{array}$ & $\begin{array}{l}\boldsymbol{k}_{\max , \boldsymbol{S R B}} \\
\text { mol }_{\mathrm{SO} 4} \text { cell }^{-1} \mathrm{~s}^{-1} \\
\end{array}$ & $\begin{array}{l}\boldsymbol{K}_{\boldsymbol{S}, \boldsymbol{F e R B}, \boldsymbol{F e}} \\
\mathrm{mol}_{\mathrm{Fe} 3} \mathrm{~L}^{-1}\end{array}$ & $\begin{array}{l}\boldsymbol{K}_{S, S R B, S O 4} \\
\text { mol }_{\text {SO4 } \mathrm{L}^{-1}} \\
\end{array}$ & $\begin{array}{l}\boldsymbol{k}_{\text {FeAbio }} \\
\mathrm{L}^{0.5} \mathrm{~mol}^{-0.5} \mathrm{~s}^{-1}\end{array}$ \\
\hline \multirow{8}{*}{ 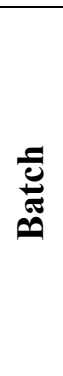 } & \multirow{2}{*}{1} & $4.50 \times 10^{-18}$ & -- & -- & -- & -- & -- \\
\hline & & $4.01 \times 10^{-18}$ & -- & -- & -- & -- & -- \\
\hline & \multirow{2}{*}{2} & $4.82 \times 10^{-18}$ & $1.82 \times 10^{-17}$ & -- & $7.93 \times 10^{-5}$ & -- & -- \\
\hline & & $4.80 \times 10^{-18}$ & $1.97 \times 10^{-17}$ & -- & $7.26 \times 10^{-5}$ & -- & -- \\
\hline & \multirow{2}{*}{3} & $2.93 \times 10^{-18}$ & -- & $8.40 \times 10^{-18}$ & -- & -- & $2.97 \times 10^{-4}$ \\
\hline & & $3.35 \times 10^{-18}$ & -- & $8.11 \times 10^{-18}$ & -- & -- & $4.31 \times 10^{-4}$ \\
\hline & \multirow{2}{*}{4} & $4.13 \times 10^{-18}$ & $2.18 \times 10^{-17}$ & $8.45 \times 10^{-17}$ & -- & $3.51 \times 10^{-4}$ & -- \\
\hline & & $3.98 \times 10^{-18}$ & $1.68 \times 10^{-17}$ & $1.60 \times 10^{-17}$ & -- & $2.91 \times 10^{-3}$ & -- \\
\hline
\end{tabular}



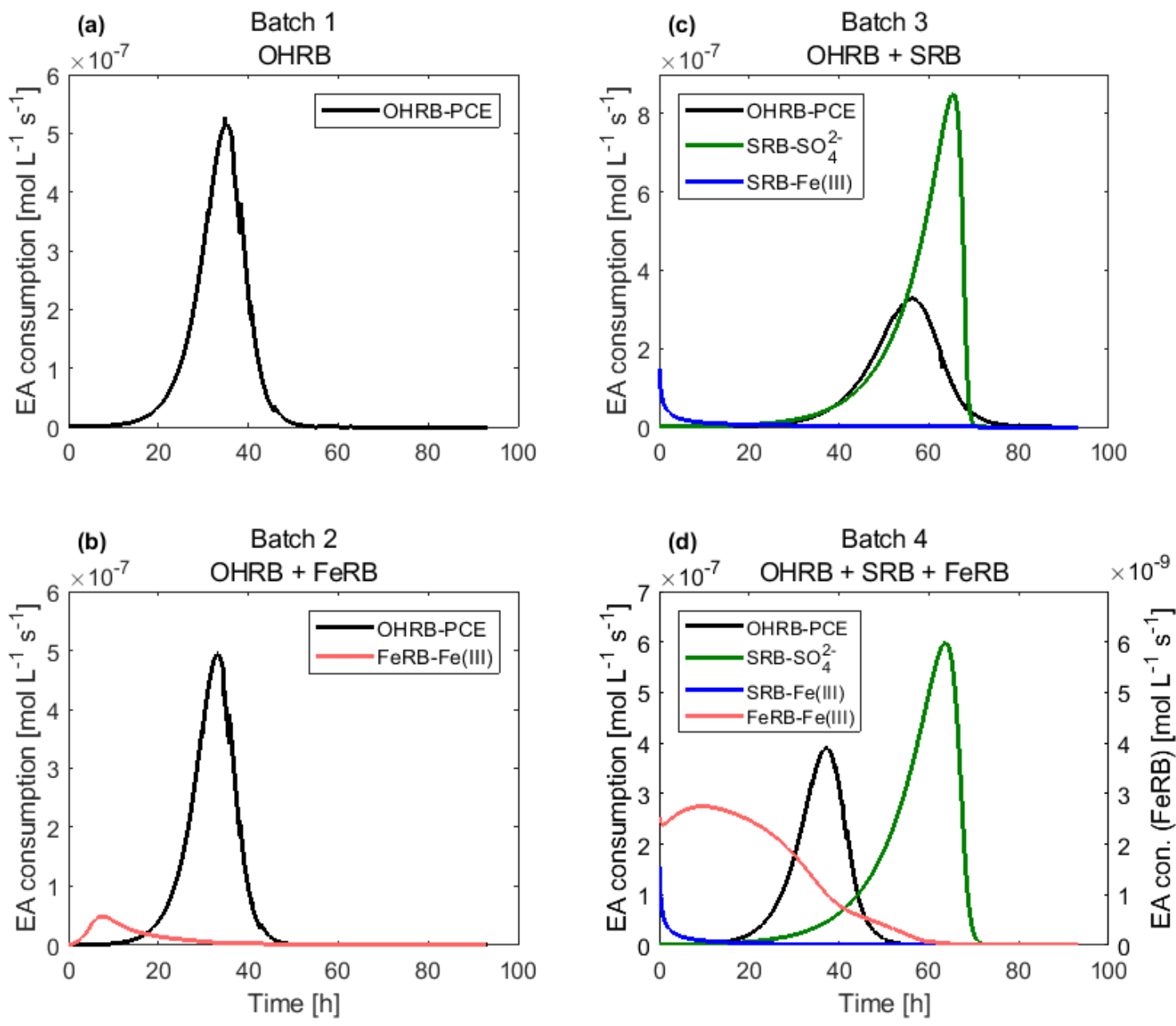

526 Figure 7. Comsumption rates for electron acceptors in batches with Batch 1: OHRB (a), Batch 2:

527 OHRB + FeRB (b), Batch 3: OHRB + SRB (c), and Batch 4: OHRB + FeRB + SRB (d).

528 When comparing Batches 1 and 2, in which the OHRB consortium was present alone and in

529 combination with FeRB (Figure $7 \mathrm{a}$ and $\mathrm{b}$ ), it is evident that there is no appreciable difference

530 between the degradation of PCE when the FeRB are and are not present, as the shape of the PCE

531 consumption peak is similar in both shape and height in both batches. The OHRB appear to behave

532 no differently whether reduction by FeRB occurs or not. This may be due to the Fe(III) speciation

533 and subsequent electron acceptor bioavailability limitation on FeRB respiration.

534 The OHRB behavior in Batch 3 is noticeably different from that of Batches 1 and 2 (Figure 7c). It is

535 evident that PCE degradation proceeds much less rapidly, as the maximum specific rate of PCE 
consumption is $65 \%$ of that observed in Batch 1 and $61 \%$ of that observed in Batch 2 (Figure $7 \mathrm{a}$ and b). The OHRB only begin to consume PCE concurrently with sulfate consumption as shown by the simulated rate curves of the 2 bacterial guilds. Such a correlation between PCE degradation and sulfate reduction has also been found in other studies (Aulenta et al., 2008; Berggren et al., 2013; Mao et al., 2015). Furthermore, in Batch 4 (Figure 7d) it appears that Fe(III) reduction by FeRB can enhance PCE reduction by OHRB, although the maximum specific degradation rate is still subdued compared to that of Batches 1 and 2. This may highlight the necessity to consider the biodiversity of the entire microbial community during bioremediation application (Aulenta et al., 2007), rather than focus on organohalide-respiring bacteria.

\section{Conclusion}

In this study we have proposed a modeling approach, based on MATLAB ${ }^{\circledR}$-PHREEQC coupling, to interpret biological assays in which microbial dynamics, mass transfer processes, and geochemical reactions can affect the degradation of organic contaminants. We performed batch experiments of

549 increasing ecological complexity on the impact of iron and sulfate reduction on PCE reductive 550 dehalogenation, and we used the proposed model to interpret the experimental observations. The model allowed us to quantify the kinetics of the different bacterial guilds and to quantitatively evaluate the effects of the physical, chemical and biological processes that occurred in the multiphase batch setups. Furthermore, the model could calculate the respiration rate throughout the 554 experimental duration, and thus the change in rate could be depicted and compared across different community compositions. The rate of PCE degradation appeared unaffected by Fe(III) respiration by FeRB, which may be due to Fe(III) bioavailability and the low Fe(III) respiration rate. Sulfate respiration by SRB did delay and decrease the PCE degradation rate; however, as was seen in the 3part community simulation, this effect was moderated by the presence of FeRB. 
559 The focus of the study was one-step dehalorespiration of PCE, however the experimental design 560 and modeling tool could be extended to more complex systems, such as multi-step degradation of 561 chlorinated ethenes and investigation of microbial competition during the transformation of further 562 PCE daughter products cis-dichloroethene and vinyl chloride. The number of guilds considered 563 could be expanded to include, for instance, fermenting organisms. Both the experimental and 564 modeling approach can be adapted to investigate degradation of different organic contaminants and 565 microbial community interactions in two-, three-, and four-phase systems and with sample removal 566 not limited to the aqueous phase. For instance, volatile compounds may be sampled and measured 567 directly from the gaseous phase.

568 The modeling tool developed in this study has a flexible structure that can be easily transferable to 569 other domains with different properties and dimensionality. For instance the reaction modules 570 developed in this work could be adapted to investigate community interactions between the same 571 microbial guilds and the feedback effects of aquatic chemistry in flow-through microcosms (Bauer 572 et al., 2009b). This will allow exploring the combined effects of solute transport processes, 573 geochemical reactions, contaminant degradation and ecological interactions in multidimensional 574 systems in which the physical and chemical heterogeneity will impact the biogeochemical processes 575 and the spatial distribution of different bacterial guilds in flow-through porous media. Similarly, the 576 reaction modules that describe microbial community and biogeochemical interactions could be 577 applied in reactive transport simulators at the field scale to help interpret the behavior of 578 groundwater contaminant plumes (e.g., Parker et al., 2008; Shani et al., 2013; Van Breukelen and 579 Rolle, 2012). 


\section{$581 \quad$ Acknowledgements}

582 This study was funded by a DTU alliance $\mathrm{PhD}$ scholarship granted to Alexandra Murray. Massimo 583 Rolle acknowledges the support of the Independent Research Fund Denmark (grant DFF-7017584 00130). Constructive comments from two anonymous reviewers helped to improve the quality of 585 the manuscript. 


\section{References}

Abe, Y., Aravena, R., Zopfi, J., Parker, B., Hunkeler, D., 2009. Evaluating the fate of chlorinated ethenes in streambed sediments by combining stable isotope, geochemical and microbial methods. J. Contam. Hydrol. 107, 10-21. https://doi.org/10.1016/j.jconhyd.2009.03.002

Aeppli, C., Berg, M., Cirpka, O.A., Holliger, C., Schwarzenbach, R.P., Hofstetter, T.B., 2009. Influence of mass-transfer limitations on carbon isotope fractionation during microbial dechlorination of trichloroethene. Environ. Sci. Technol. 43, 8813-8820. https://doi.org/10.1021/es901481b

Amos, B.K., Christ, J.A., Abriola, L.M., Pennell, K.D., Löffler, F.E., 2007. Experimental evaluation and mathematical modeling of microbially enhanced tetrachloroethene (PCE) dissolution. Environ. Sci. Technol. 41, 963-970. https://doi.org/10.1021/es061438n

Appelo, C.A.J., Postma, D., 2005. Geochemistry, groundwater and pollution, Second. ed. A.A. Balkema Publishers, Leiden.

Aulenta, F., Beccari, M., Majone, M., Papini, M.P., Tandoi, V., 2008. Competition for H2 between sulfate reduction and dechlorination in butyrate-fed anaerobic cultures. Process Biochem. 43, 161-168. https://doi.org/10.1016/j.procbio.2007.11.006

Aulenta, F., Pera, A., Rossetti, S., Petrangeli Papini, M., Majone, M., 2007. Relevance of side reactions in anaerobic reductive dechlorination microcosms amended with different electron donors. Water Res 41, 27-38. https://doi.org/10.1016/j.watres.2006.09.019

Badziong, W., Thauer, R.K., 1978. Growth yields and growth rates of Desulfovibrio vulgaris (Marburg) growing on hydrogen plus sulfate and hydrogen plus thiosulfate as the sole energy sources. Arch. Microbiol. 117, 209-214. https://doi.org/10.1007/bf00402310 
Balkwill, D.L., Leach, F.R., Wilson, J.T., Mcnabb, J.F., White, D.C., 1988. Equivalence of Microbial Biomass Measures Based on Membrane Lipid and Cell Wall Components, Adenosine Triphosphate, and Direct Counts in Subsurface Aquifer Sediments Abstract . 73 84.

Bauer, R.D., Rolle, M., Bauer, S., Eberhardt, C., Grathwohl, P., Kolditz, O., Meckenstock, R.U., Griebler, C., 2009. Enhanced biodegradation by hydraulic heterogeneities in petroleum hydrocarbon plumes. J. Contam. Hydrol. 105, 56-68. https://doi.org/10.1016/j.jconhyd.2008.11.004

Bauer, R.D., Rolle, M., Kürzinger, P., Grathwohl, P., Meckenstock, R.U., Griebler, C., 2009. Twodimensional flow-through microcosms - Versatile test systems to study biodegradation processes in porous aquifers. J. Hydrol. 369, 284-295. https://doi.org/10.1016/j.jhydrol.2009.02.037

Berggren, D.R. V, Marshall, I.P.G., Azizian, M.F., Spormann, A.M., Semprini, L., 2013. Effects of sulfate reduction on the bacterial community and kinetic parameters of a dechlorinating culture under chemostat growth conditions. Environ. Sci. Technol. 47, 1879-1886. https://doi.org/10.1021/es304244z

Buchner, D., Jin, B., Ebert, K., Rolle, M., Elsner, M., Haderlein, S.B., 2016. Experimental Determination of Isotope Enrichment Factors - Bias from Mass Removal by Repetitive Sampling. Environ. Sci. Technol. acs.est.6b03689. https://doi.org/10.1021/acs.est.6b03689

Buttet, G.F., Holliger, C., Maillard, J., 2013. Functional genotyping of Sulfurospirillum spp. in mixed cultures allowed the identification of a new tetrachloroethene reductive dehalogenase. Appl. Environ. Microbiol. 79. https://doi.org/10.1128/AEM.02312-13 
Buttet, G.F., Murray, A.M., Goris, T., Burion, M., Jin, B., Rolle, M., Holliger, C., Maillard, J., 2018. Coexistence of two distinct Sulfurospirillum populations respiring tetrachloroethenegenomic and kinetic considerations. FEMS Microbiol. Ecol. 94, 1-11. https://doi.org/10.1093/femsec/fiy018

Chambon, J.C., Bjerg, P.L., Scheutz, C., Bælum, J., Jakobsen, R., Binning, P.J., 2013. Review of reactive kinetic models describing reductive dechlorination of chlorinated ethenes in soil and groundwater. Biotechnol. Bioeng. 110, 1-23. https://doi.org/10.1002/bit.24714

Charlton, S.R., Parkhurst, D.L., 2011. Modules based on the geochemical model PHREEQC for use in scripting and programming languages. Comput. Geosci. 37, 1653-1663. https://doi.org/10.1016/j.cageo.2011.02.005

Cypionka, H., 2000. Oxygen respiration by Desulfovibrio species. Annu. Rev. Microbiol. 54, 82748.

Daugulis, A.J., 2001. Two-phase partitioning bioreactors: A new technology platform for destroying xenobiotics. Trends Biotechnol. 19, 457-462. https://doi.org/10.1016/S01677799(01)01789-9

Déziel, E., Comeau, Y., Villemur, R., 1999. Two-liquid-phase bioreactors for enhanced degradation of hydrophobic/toxic compounds. Biodegradation 10, 219-233. https://doi.org/10.1023/A:1008311430525

Elias, D.A., Suflita, J.M., McInerney, M.J., Krumholz, L.R., 2004. Periplasmic Cytochrome c3 of Desulfovibrio vulgaris is directly involved in H2-mediated metal but not sulfate reduction. Appl. Environ. Microbiol. 70, 413-420. https://doi.org/10.1128/AEM.70.1.413

Fredrickson, J.K., Romine, M.F., Beliaev, A.S., Auchtung, J.M., Driscoll, M.E., Gardner, T.S., 
Nealson, K.H., Osterman, A.L., Pinchuk, G., Reed, J.L., Rodionov, D. a, Rodrigues, J.L.M., Saffarini, D. a, Serres, M.H., Spormann, A.M., Zhulin, I.B., Tiedje, J.M., 2008. Towards environmental systems biology of Shewanella. Nat. Rev. Microbiol. 6, 592-603. https://doi.org/10.1038/nrmicro1947

Gadd, G.M., 2010. Metals, minerals and microbes: Geomicrobiology and bioremediation. Microbiology 156, 609-643. https://doi.org/10.1099/mic.0.037143-0

Haas, J.R., Dichristina, T.J., 2002. Effects of FE(III) chemical speciation on dissimilatory FE(III) reduction by shewanella putrefaciens. Environ. Sci. Technol. 36, 373-380. https://doi.org/10.1021/es0109287

Haberer, C.M., Muniruzzaman, M., Grathwohl, P., Rolle, M., 2015. Diffusive-Dispersive and Reactive Fronts in Porous Media: Iron(II) Oxidation at the Unsaturated-Saturated Interface. Vadose Zo. J. 14, 1-14. https://doi.org/10.2136/vzj2014.07.0091

Hamonts, K., Kuhn, T., Vos, J., Maesen, M., Kalka, H., Smidt, H., Springael, D., Meckenstock, R.U., Dejonghe, W., 2012. Temporal variations in natural attenuation of chlorinated aliphatic hydrocarbons in eutrophic river sediments impacted by a contaminated groundwater plume. Water Res. 46, 1873-1888. https://doi.org/10.1016/j.watres.2012.01.001

Heidelberg, J.F., Paulsen, I.T., Nelson, K.E., Gaidos, E.J., Nelson, W.C., Read, T.D., Eisen, J. a, Seshadri, R., Ward, N., Methe, B., Clayton, R. a, Meyer, T., Tsapin, A., Scott, J., Beanan, M., Brinkac, L., Daugherty, S., DeBoy, R.T., Dodson, R.J., Durkin, a S., Haft, D.H., Kolonay, J.F., Madupu, R., Peterson, J.D., Umayam, L. a, White, O., Wolf, A.M., Vamathevan, J., Weidman, J., Impraim, M., Lee, K., Berry, K., Lee, C., Mueller, J., Khouri, H., Gill, J., Utterback, T.R., McDonald, L. a, Feldblyum, T. V, Smith, H.O., Venter, J.C., Nealson, K.H., Fraser, C.M., 2002. Genome sequence of the dissimilatory metal ion-reducing bacterium 
Heidelberg, J.F., Seshadri, R., Haveman, S.A., Hemme, C.L., Paulsen, I.T., Kolonay, J.F., Eisen, J.A., Ward, N., Methe, B., Brinkac, L.M., Daugherty, S.C., Deboy, R.T., Dodson, R.J., Durkin, A.S., Madupu, R., Nelson, W.C., Sullivan, S.A., Fouts, D., Haft, D.H., Selengut, J., Peterson,

Imfeld, G., Nijenhuis, I., Nikolausz, M., Zeiger, S., Paschke, H., Drangmeister, J., Grossmann, J.,

Holliger, C., Schraa, G., Stams, A.J.M., Zehnder, A.J.B., 1993. A highly purified enrichment culture couples the reductive dechlorination of tetrachloroethene to growth. Appl. Environ. Microbiol. 59, 2991-2997. J.D., Davidsen, T.M., Zafar, N., Zhou, L., Radune, D., Dimitrov, G., Hance, M., Tran, K., Khouri, H., Gill, J., Utterback, T.R., Feldblyum, T. V, Wall, J.D., Voordouw, G., Fraser, C.M., 2004. The genome sequence of the anaerobic, sulfate-reducing bacterium Desulfovibrio vulgaris Hildenborough. Nat. Biotechnol. 22, 554-559. https://doi.org/10.1038/nbt959

Richnow, H.H., Weber, S., 2008. Assessment of in situ degradation of chlorinated ethenes and bacterial community structure in a complex contaminated groundwater system. Water Res. 42, 871-882. https://doi.org/10.1016/j.watres.2007.08.035

Jakobsen, R., 2007. Redox microniches in groundwater: A model study on the geometric and kinetic conditions required for concomitant Fe oxide reduction, sulfate reduction, and methanogenesis. Water Resour. Res. 43. https://doi.org/10.1029/2006WR005663

Jin, B., Haderlein, S.B., Rolle, M., 2013. Integrated carbon and chlorine isotope modeling: Applications to chlorinated aliphatic hydrocarbons dechlorination. Environ. Sci. Technol. 47, 
Kampara, M., Thullner, M., Richnow, H.H., Harms, H., Wick, L.Y., 2008. Impact of Bioavailability Restrictions on Microbially Induced Stable Isotope Fractionation. 2. Experimental Evidence. Environ. Sci. Technol. 42, 6544-6551. https://doi.org/Doi 10.1021/Es702781x

Kotik, M., Davidová, A., Voříšková, J., Baldrian, P., 2013. Bacterial communities in tetrachloroethene-polluted groundwaters: a case study. Sci. Total Environ. 454-455, 517-27. https://doi.org/10.1016/j.scitotenv.2013.02.082

Kouznetsova, I., Mao, X., Robinson, C., Barry, D. a., Gerhard, J.I., McCarty, P.L., 2010. Biological reduction of chlorinated solvents: Batch-scale geochemical modeling. Adv. Water Resour. 33, 969-986. https://doi.org/10.1016/j.advwatres.2010.04.017

Liu, C., Zachara, J.M., Gorby, Y.A., Szecsody, J.E., Brown, C.F., 2001. Microbial reduction of $\mathrm{Fe}(\mathrm{III})$ and sorption/precipitation of Fe(II) on Shewanella putrefaciens strain CN32. Environ. Sci. Technol. 35, 1385-1393. https://doi.org/10.1021/es0015139

Malaguerra, F., Chambon, J.C., Bjerg, P.L., Scheutz, C., Binning, P.J., 2011. Development and sensitivity analysis of a fully kinetic model of sequential reductive dechlorination in groundwater. Environ. Sci. Technol. 45, 8395-8402. https://doi.org/10.1021/es201270z

Mao, X., Stenuit, B., Polasko, A., Alvarez-Cohen, L., 2015. Efficient metabolic exchange and electron transfer within a syntrophic trichloroethene-degrading coculture of Dehalococcoides mccartyi 195 and Syntrophomonas wolfei. Appl. Environ. Microbiol. 81, 2015-2024. https://doi.org/10.1128/AEM.03464-14

Marcus, I.M., Wilder, H.A., Quazi, S.J., Walker, S.L., 2013. Linking microbial community structure to function in representative simulated systems. Appl. Environ. Microbiol. 79, $2552-$ 
Meckenstock, R.U., Elsner, M., Griebler, C., Lueders, T., Stumpp, C., Dejonghe, W., Bastiaens, L.L., Springael, D., Smolders, E., Boon, N., Agathos, S.N., Sorensen, S.R., Aamand, J., Albrechtsen, H.J., Bjerg, P.L., Schmidt, S., Huang, W.E., Van Breukelen, B.M., 2015. Biodegradation: Updating the concepts of control for microbial clean-up in contaminated aquifers. Environ. Sci. Technol. 49, 7073-7081. https://doi.org/10.1021/acs.est.5b00715

Muniruzzaman, M., Rolle, M., 2016. Modeling multicomponent ionic transport in groundwater with IPhreeqc coupling: Electrostatic interactions and geochemical reactions in homogeneous and heterogeneous domains. Adv. Water Resour. 98, 1-15. https://doi.org/10.1016/j.advwatres.2016.10.013

Murray, A., Ottosen, C.B., Maillard, J., Holliger, C., Johansen, A., Brabæk, L., Kristensen, I.L., Zimmermann, J., Hunkeler, D., Broholm, M.M., n.d. Chlorinated ethene plume evolution after source thermal remediation: determination of degradation rates and mechanisms. J. Contam. Hydrol.

Noguera, D., Brusseau, G., Rittmann, B., Stahl, D., 1998. A unified model describing the role of hydrogen in the growth of desulfovibrio vulgaris under different environmental conditions. Biotechnol. Bioeng. 59, 732-46. https://doi.org/10.1002/(sici)10970290(19980920)59:6<732::aid-bit10>3.3.co;2-2

Park, H.S., Lin, S., Voordouw, G., 2008. Ferric iron reduction by Desulfovibrio vulgaris Hildenborough wild type and energy metabolism mutants. Antonie van Leeuwenhoek, Int. J. Gen. Mol. Microbiol. 93, 79-85. https://doi.org/10.1007/s10482-007-9181-3 

from thin clay layers in a sand aquifer following TCE source-zone hydraulic isolation. J. Contam. Hydrol. 102, 86-104. https://doi.org/10.1016/j.jconhyd.2008.07.003

Parkhurst, D.L., Appelo, C.A.J., 2013. Description of input and examples for PHREEQC Version 3 - A computer program for speciation, batch-reaction, one-dimensional transport, and inverse geochemical calculations. U.S. Geol. Surv. Tech. Methods, B. 6, chapter A43 6-43A. https://doi.org/10.1016/0029-6554(94)90020-5

Postma, D., Jakobsen, R., 1996. Redox zonation: Equilibrium constraints on the Fe(III)/SO4reduction interface. Geochim. Cosmochim. Acta 60, 3169-3175.

Poulton, S.W., Krom, M.D., Raiswell, R., 2004. A revised scheme for the reactivity of iron (oxyhydr) oxide minerals towards dissolved sulfide. Geochim. Cosmochim. Acta 68, 37033715. https://doi.org/10.1016/j.gca.2004.03.012

Prommer, H., Anneser, B., Rolle, M., Einsiedl, F., Griebler, C., 2009. Biogeochemical and isotopic gradients in a BTEX/PAH contaminant plume: Model-based interpretation of a high-resolution field data set. Environ. Sci. Technol. 43, 8206-8212. https://doi.org/10.1021/es901142a

Remoundaki, E., Kousi, P., Joulian, C., Battaglia-Brunet, F., Hatzikioseyian, A., Tsezos, M., 2008. Characterization, morphology and composition of biofilm and precipitates from a sulphatereducing fixed-bed reactor. J. Hazard. Mater. 153, 514-524. https://doi.org/10.1016/j.jhazmat.2007.08.094

Rickard, D., 1995. Kinetics of FeS precipitation: Part 1. Competing reaction mechanisms. Geochim. Cosmochim. Acta 59, 4367-4379. https://doi.org/10.1016/0016-7037(95)00251-T

Rickard, D., Luther, G.W., 2007. Chemistry of iron sulfides, Chemical Reviews. https://doi.org/10.1021/cr0503658 
Rittmann, B.E., McCarty, P.L., 2001. Environmental Biotechnology: Principles and Applications, First. ed. McGraw-Hill, New York.

Rolle, M., Chiogna, G., Bauer, R., Griebler, C., Grathwohl, P., 2010. Isotopic fractionation by transverse dispersion: Flow-through microcosms and reactive transport modeling study. Environ. Sci. Technol. 44, 6167-6173. https://doi.org/10.1021/es101179f

Rolle, M., Kitanidis, P.K., 2014. Effects of compound-specific dilution on transient transport and solute breakthrough: A pore-scale analysis. Adv. Water Resour. 71, 186-199. https://doi.org/10.1016/j.advwatres.2014.06.012

Rolle, M., Sprocati, R., Masi, M., Jin, B., Muniruzzaman, M., 2018. Nernst-Planck-based Description of Transport, Coulombic Interactions, and Geochemical Reactions in Porous Media: Modeling Approach and Benchmark Experiments. Water Resour. Res. 54, 3176-3195. https://doi.org/10.1002/2017WR022344

Schneidewind, U., Haest, P.J., Atashgahi, S., Maphosa, F., Hamonts, K., Maesen, M., Calderer, M., Seuntjens, P., Smidt, H., Springael, D., Dejonghe, W., 2014. Kinetics of dechlorination by Dehalococcoides mccartyi using different carbon sources. J. Contam. Hydrol. 157, 25-36. https://doi.org/10.1016/j.jconhyd.2013.10.006

Scholz-Muramatsu, H., Neumann, A., Messmer, M., Moore, E., Diekert, G., 1995. Isolation and characterization of Dehalospirillum multivorans gen . nov ., sp . nov ., a tetrachloroetheneutilizing , strictly anaerobic bacterium. Arch. Microbiol. 163, 48-56.

Shani, N., Rossi, P., Holliger, C., 2013. Correlations between environmental variables and bacterial community structures suggest Fe(III) and vinyl chloride reduction as antagonistic terminal electron-accepting processes. Environ. Sci. Technol. 47, 6836-6845. 
https://doi.org/10.1021/es304017s

Tang, Y.J., Meadows, A.L., Keasling, J.D., 2007. A kinetic model describing Shewanella oneidensis MR-1 growth, substrate consumption, and product secretion. Biotechnol. Bioeng. 96, 125-133. https://doi.org/10.1002/bit

Tao, X., Li, Y., Huang, H., Chen, Y., Liu, P., Li, X., 2014. Desulfovibrio vulgaris Hildenborough prefers lactate over hydrogen as electron donor. Ann. Microbiol. 64, 451-457. https://doi.org/10.1007/s13213-013-0675-0

Thullner, M., Fischer, A., Richnow, H.H., Wick, L.Y., 2012. Influence of mass transfer on stable isotope fractionation. Appl. Microbiol. Biotechnol. 97, 441-452. https://doi.org/10.1007/s00253-012-4537-7

Thullner, M., Kampara, M., Richnow, H.H., Harms, H., Wick, L.Y., 2008. Impact of Bioavailability Restrictions on Microbially Induced Stable Isotope Fractionation. 1. Theoretical Calculation. Environ. Sci. Technol. 42, 6544-6551. https://doi.org/Doi 10.1021/Es702781x

Van Breukelen, B.M., Rolle, M., 2012. Transverse hydrodynamic dispersion effects on isotope signals in groundwater chlorinated solvents plumes. Environ. Sci. Technol. 46, 7700-7708. https://doi.org/10.1021/es301058z

Van Breukelen, B.M., Thouement, H.A.A., Stack, P.E., Vanderford, M., Philp, P., Kuder, T., 2017. Modeling 3D-CSIA data: Carbon, chlorine, and hydrogen isotope fractionation during reductive dechlorination of TCE to ethene. J. Contam. Hydrol. 204, 79-89. https://doi.org/10.1016/j.jconhyd.2017.07.003

Viollier, E., Inglett, P.W., Hunter, K., Roychoudhury, A.N., Van Cappellen, P., 2000. The ferrozine method revisited: $\mathrm{Fe}(\mathrm{II}) / \mathrm{Fe}(\mathrm{III})$ determination in natural waters. Appl. Geochemistry 15, 785- 
Wade, M.J., Harmand, J., Benyahia, B., Bouchez, T., Chaillou, S., Cloez, B., Godon, J.J., Moussa Boudjemaa, B., Rapaport, A., Sari, T., Arditi, R., Lobry, C., 2016. Perspectives in mathematical modelling for microbial ecology. Ecol. Modell. 321, 64-74.

Wells, G.F., Park, H.D., Eggleston, B., Francis, C.A., Criddle, C.S., 2011. Fine-scale bacterial https://doi.org/10.1016/j.ecolmodel.2015.11.002

Weatherill, J.J., Atashgahi, S., Schneidewind, U., Krause, S., Ullah, S., Cassidy, N., Rivett, M.O.,

2018. Natural attenuation of chlorinated ethenes in hyporheic zones: A review of key

biogeochemical processes and in-situ transformation potential. Water Res. 128, 362-382.

https://doi.org/10.1016/j.watres.2017.10.059

community dynamics and the taxa-time relationship within a full-scale activated sludge

bioreactor. Water Res. 45, 5476-5488. https://doi.org/10.1016/j.watres.2011.08.006

Wissmeier, L., Barry, D.A., 2011. Simulation tool for variably saturated flow with comprehensive

geochemical reactions in two- and three-dimensional domains. Environ. Model. Softw. 26, 210-218. https://doi.org/10.1016/j.envsoft.2010.07.005

Xu, G., Lu, Q., Yu, L., Wang, S., 2019. Tetrachloroethene Primes Reductive Dechlorination of Polychlorinated Biphenyls in a River Sediment Microcosm. Water Res. 152, 87-95. https://doi.org/10.1016/j.watres.2018.12.061

Yu, S., Semprini, L., 2004. Kinetics and modeling of reductive dechlorination at high PCE and TCE concentrations. Biotechnol. Bioeng. 88, 451-464. https://doi.org/10.1002/bit.20260

Yu, S., Semprini, L., 2002. Comparison of trichloroethylene reductive dehalogenation by microbial communities stimulated on silicon-based organic compounds as slow-release anaerobic 
830 Zhou, C., Vannela, R., Hayes, K.F., Rittmann, B.E., 2014. Effect of growth conditions on microbial 831 activity and iron-sulfide production by Desulfovibrio vulgaris. J. Hazard. Mater. 272, 28-35. $832 \quad$ https://doi.org/10.1016/j.jhazmat.2014.02.046

833 Zhou, C., Zhou, Y., Rittmann, B.E., 2017. Reductive precipitation of sulfate and soluble Fe(III) by 834 Desulfovibrio vulgaris: Electron donor regulates intracellular electron flow and nano-FeS crystallization. Water Res. 119, 91-101. https://doi.org/10.1016/j.watres.2017.04.044 